\title{
Short-run and Long-run Expectations of the Yen/Dollar Exchange Rate
}

\author{
Takatoshi Ito
}

Working Paper No. 82

\author{
Takatoshi Ito \\ Harvard University \\ Hitotsubashi University \\ and \\ National Bureau of Economic Research \\ Revised, October 1993
}

\begin{abstract}
* An earlier version of this paper, under the title of "Short-run and Long-run Behavior of the Foreign Exchange Rate" was presented at the conference, Japan in a Global Economy in Stockholm. I thank Mr. Kumiharu Shigehara, Professor Lars Oxelheim and other participants of the conference for their comments at the conference. Research assistance by Graham Elliott was extremely helpful. The Japan Center for International Finance was kind enough to provide their survey data. Financial support from National Science Foundation is gratefully acknowledged. Updates and revision of the paper was made possible by the Visiting Scholar program at the International Monetary Fund.
\end{abstract}

Working Paper Series

Center on Japanese Economy and Business

Graduate School of Business

Columbia University

December 1993 


\section{Short-run and Long-run Expectations of the Yen/Dollar Exchange Rate} (abstract)

\section{Takatoshi Ito}

The survey data of the yen/dollar exchange rate, collected twice a month for eight years from 1985 to 1993, shows the following features. First, the expected exchange rate changes in the short horizon (one month) is of the band-wagon type while the expected changes in the long horizon (three to six months) is of the mean-reversion type. That is, foreign exchange traders infers from recent appreciations or depreciation that the recent change in the exchange rate will continue for a while, but the direction of changes will reverse, eventually. Second, this result is robust for the entire sample period, which includes sub-periods of sharp yen appreciations and of relative calm, and with respect to different specifications. Third, the deviation from an equilibrium exchange rate does not yield a robust estimate in the regression of expectation formation. Although the history of the yen/dollar exchange rate fluctuations in the past two decades shows mean reversion over several years, they are not captured in the six-month expectations in the survey data.

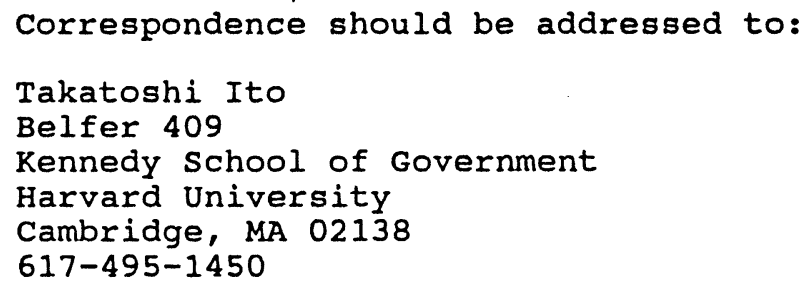




\section{Introduction}

The behavior of foreign exchange rates has been a popular subject in the international finance literature ever since the break down of the Bretton Woods system in the early 1970s. In the following two decades, we have found several "regularities" and "stylized facts" on the exchange rate dynamics. One of the salient features about the exchange rate movement is that the exchange rate is close to a random walk in the fine frequencies, say daily data, but has serial correlation in the lower frequency data, say in the quarterly data. For very low frequencies, say a decade or so, the exchange rate seems to be cyclical. However, the exchange rate can deviate from an equilibrium exchange rate (or a range loosely defined as such) for a significant length of time. The experience of the over-appreciated dollar in the first half of the 1980s is an obvious example of this. It is still a challenge to present an internally-consistent model with a random walk behavior in the short run with low-frequency cycles around the equilibrium rate in the long run. Engel and Hamilton (1990) described it as a switching between two different processes of random walk with a trend. Frankel and Froot (1988) and Froot and Frankel (1990) employed a simulation model of a market comprised of two different kinds of participants, chartists and fundamentalists.

One way to advance our understanding of exchange rate movements is to model and estimate directly expectations of market participants, since a majority of the foreign transactions are for capital transactions reflecting exchange rate expectations, rather than current account transactions. Expectations of market participants, traders and investors, can be used to test how they perceive the exchange rate to behave in the short and long run. 
As survey data on the exchange rate expectations have become available during the 1980s, many have conducted empirical investigations on expectation formations. (See Dominguez (1986), Frankel and Froot (1987a) and Ito (1990) to name a few. Also see Takagi (1991) for the "survey of the survey literature." $)^{1}$ It has been established that expectations for the short horizon, say one week to one month, tend to be more of the bandwagon type (that is, the exchange rate will continue to change in the same direction as the recent changes) and expectations for the long horizon, say three months to six months, tend to be mean reverting (that is, it will reverse the direction of change, and will go back to an "anchor"). (See Frankel and Froot (1987b), and Froot and Ito (1989).)

This paper will advance this line of investigation one step further and investigate whether agents realize the existence of a long-run anchor of the exchange rate. To that end, I will define an equilibrium rate of the yen/dollar rate, and investigate whether the deviation from the equilibrium has any impact on the expectation formation.

The rest of this paper consists of the following sections. Section 2 describes, in quarterly data, the two-decade history of the yen/dollar rate since 1973. In Section 3, the survey data, available for 1985 to 1993, used in this paper is introduced and examined for general characteristics. Regression analyses to study expectation formation is conducted in Sections 4,5 , and 6 . Section 7 concludes with summary and future direction of the research.

\section{The Yen/Dollar Exchange Rate, 1973-1993}

The quarterly yen/dollar exchange rate is plotted, as the solid line, from 1973 to 1993 in Figure $1 .^{2}$ The solid-line exchange rate movement clearly shows the long run trend and fluctuations around it. In order to highlight this characteristic, the upper broken line is 
drawn as a log-linear "trend" in the sample period, and denoted by SEQ3(t). ${ }^{3}$ Once the exchange rate crosses this line, it tends to stay above or below at least for several quarters. There is a strond persistence (positive correlation) in the quarterly yen/dollar rate movement. Vertical lines shows the beginning and end of each subperiod of survey data to be introduced in the next section of the paper.

The lower broken line is drawn as an approximate level of the yen/dollar exchange rate to balance current accounts. Without significant capital movement or official interventions, current account surpluses (deficits) tend to appreciate (depreciate) its currency. The Bretton Woods system collapsed in August 1971, and the yen departed from the rate of 360 yen/dollar which had been fixed since 1949. Japan has in general recorded current account surpluses in the post-Bretton Woods system, but its current account went into deficits in five years, 1973-75 and 1979-80. The United States experienced in general current account deficits after 1971, except 1973-1976, and 1980-81. Note that in 1973 and 1979, the Japanese current accounts, as well as the United States, were close to zero. Hence, we may regard the exchange rate at that time may be close to its equilibrium level in the sense of balancing current accounts of the two countries. Hence, we will take fourquarter averages of the yen/dollar rates are substituted in 1973:2 and 1979:2. ${ }^{4}$ Then the log-linear trend is fit between these two quarters and then extrapolated beyond 1979. Let us call this (lower) broken line in Figure 1 "the equilibrium exchange rate," since the two benchmark points were chosen for years when current accounts were balanced. The logarithm of the equilibrium exchange rate is denoted by SEQ2(t).

It is obvious from the figure that the difference between the two broken lines happens to stay relatively constant. (See appendix for exact numbers.) 
In order to characterize the long-run behavior, the quarterly exchange rate is regressed on the lagged exchange rate change and the deviation from the long-run trend, where the long run trend is defined either by the sample trend, seq3, or the equilibrium, seq2. Hence, the following regression is estimated:

$s(t)-s(t-1)=a+b *(s(t-2)-s(t-1))+c^{*}(\operatorname{seg} j(t-1)-s(t-1))+e(t)$

where $s(t)$ is the log of the yen/dollar rate, averaged over quarter $t$, and seqj $(t)$ is the log of the long-run exchange rate $(j=2$ or 3 ) defined above and $e(t)$ is the disturbance term. Note that equation (1) can be transformed as the following, ignoring the disturbance term:

$$
s(t)=a+b^{*} s(t-2)+c^{*} \operatorname{seq}(t-1)+\{1-b-c\}^{*} s(t-1)
$$

Namely, the spot rate of period $t$ is a weighted average of the spot rates of $t-1$ and $t-2$ and the long-run spot rate.

In a special case, if coefficient $\mathrm{a}$ and $\mathrm{c}$ are zeros, coefficient $\mathrm{b}$ becomes the weight on the $s(t-2)$ where $s(t)$ is the weighted average of $s(t-1)$ and $s(t-2)$; while if coefficients a and $\mathrm{b}$ are zeros, coefficient $\mathrm{c}$ becomes the weight on segj(t) where $\mathrm{s}(\mathrm{t})$ is the weighted average of $s(t-1)$ and seqj $(t)$. Hence, the following interpretation is natural. If $b$ is negative, then, other things being equal, it implies a positive serial correlation in exchange rate change, namely, the direction of change in the exchange rate from $t-2$ to $t-1$ tends to continue from $\mathrm{t}-1$ to $\mathrm{t}$. If $\mathrm{c}$ is positive, then, controlling for other factors, the exchange rate tends to return to return to the long-run equilibrium, seqj.

Results of the estimation, with several variations on special cases and choice of definitions for the long-run equilibrium, on the definition, are shown in Table 1. 
The table shows that (i) when the exchange rate appreciates 1 percent from $t-2$ to $t-1$, it tends to appreciate about 0.4 percent from $t-1$ to $t$, and (ii) a 1 percent deviation of the exchange from the long-run equilibrium at $\mathrm{t}-1$ tends to cause a $0.1 \%$ change toward the equilibrium. The first effect implies a bandwagon type behavior, that is, once the rate moves in one direction (appreciation or depreciation), it tends to continue in that direction. The second effect implies a mean-reversion type behavior such that in the long run, the rate will return to the equilibrium. Although the coefficient of the second effect is small in magnitude, the deviation variable will become increasingly important if the rate continues to deviate due to the first effect.

To explain the phenomenon of short-run bandwagon and long-run mean-reversion, Frankel and Froot $(1990$ a,b) suggested a model with two types of agents, chartists and fundamentalists. Their model can be understood as follows. The chartists believe that the exchange rate follows a random walk, or in a more complicated model, a bandwagon (explosive) type process. The fundamentalists expect that the exchange rate returns to the equilibrium rate defined by fundamentals. There is a third type of agent, institutional investors, who allocates funds to chartists and fundamentalists depending on the success of past forecasts. If chartists are successful, more funds are allocated to chartists. Then their (financial) weight in the market increases, which makes it more probable that the true process follows a bandwagon, chartists' belief. As the exchange rate deviates more and more from the equilibrium rate, risk of collapse increases because of the feedback from the real side of the economy. Sooner or later, the fundamentals work and start pulling the exchange rate back to the equilibrium rate. Once the rate turns around, the bandwagon works to restore fundamentals. A simulation of this type of theoretical models, shown by 
Frankel and Froot (1990a), is broadly consistent with the exchange rate behavior, that is a low-frequency fluctuation around the equilibrium rate as just like in Figure 1. However, an exact structural model that is amenable to estimation has not been developed.

Engel and Hamilton (1990) develop a model of switching random walks. They explained "long swings" in the dollar as switching between the random walk processes with different trends, with stochastic switching between the processes. Even with a small probability of switching, the process eventually switches with a sufficiently long time, thus the long swing.

The evidence presented in Figure 1 is consistent with a scenario of fundamentalists and chartists, a la Frankel and Froot, or with a switching model like Engel and Hamilton. The quarterly exchange rate movement shows the bandwagon behavior in the short-run and the mean-reversion in the long-run. Knowing that the exchange rate behaves as above, how do market participants form their expectations? This is the next topic of investigation.

\section{Preliminary Analysis: Survey Data}

The Japan Center for International Finance (JCIF) in Tokyo has been conducting a yen/dollar exchange rate expectation survey twice a month since May 1985. The survey is conducted by telephone interviews. The polls had been taken on Wednesdays until 1989, when they were switched to on Tuesdays. The interval between surveys is usually two weeks and sometimes three weeks so that surveys are conducted both near the middle of the month and near the end of the month. The average of 44 participants in the survey is announced by JCIF, on the day after the survey. ${ }^{5}$ In this paper, we use data for the 192 surveys from May 1985 to August $1993 .^{6}$ 
In preparation for analyzing expectations formations of short and long horizons, expectations variables and actual changes are defined as follows. The $\mathrm{k}$-month(s) ahead expectation of the yen/dollar rate surveyed at period $t$ is denoted by $\mathrm{ES}(\mathrm{t}, 2 \mathrm{k}), \mathrm{k}=1,3,6$. Note that $k$ denotes months, while observation frequency is half months, so that $2 k$ is added in the time period. The yen/dollar rate quoted as the Tokyo market closing of the survey day is denoted by $S(t)$. The expected change, denoted by $S E k(t)$, is defined in percentage as

$$
\operatorname{SEk}(\mathrm{t})=100 *(\operatorname{ES} k(\mathrm{t}+2 \mathrm{k})-\mathrm{S}(\mathrm{t})) / \mathrm{S}(\mathrm{t}), \mathrm{k}=1,3,6 .
$$

where $t+2 k$ means (two times $k$ ) observations after period $t$. For example, for 1 -month expectation $(k=1)$, expectation is for the rate to be recorded at two observations later, since the observational frequency is half month.

The actual two-week change, denoted by $\operatorname{DSP}(t)$, is defined in percentage as

$$
\operatorname{DSP}(\mathrm{t})=100 *(\mathrm{~S}(\mathrm{t})-\mathrm{S}(\mathrm{t}-1)) / \mathrm{S}(\mathrm{t})
$$

The forecast errors is defined as,

$$
\operatorname{FEk}(\mathrm{t})=100 *(\mathrm{ESk}(\mathrm{t}+2 \mathrm{k})-\mathrm{S}(\mathrm{t}+2 \mathrm{k})) / \mathrm{S}(\mathrm{t}) .
$$

In Table 2, some summary statistics, time-series mean and standard deviations, of SEk $(k=1,3,6)$, CHG, and FEk $(k=1,3,6)$ for the entire sample period and four equally divided subsamples are shown. Also shown is the accumulated change (Change sum) of the exchange rate, defined as the difference between the spot rate of the last survey date of the (sub)period and the last survey date of the preceding (sub)period. ${ }^{?}$

*** insert Table 2 about here

From Figure 1 and Table 2, it is quite obvious that the yen had experienced a steep appreciation from 1985 to 1987 , followed by a period of stability of four years. During 
the period of 1991-1993 the market also experienced a relatively mild yen appreciation. ${ }^{8}$ Hence, expectations formation and forecast errors may behave quite differently before and after 1987. In the following analysis, therefore, results are presented for the entire eight years, and also for four two-year subsamples.

In subperiod I (June 1985-June 1987), the yen appreciated roughly from the level of 250 to 140 almost monotonically. This subperiod roughly corresponds to the period when the Group of Five countries decided to depreciate the U.S. dollar at the Plaza meeting (September 1985), and then agreed to stabilize the exchange rate in a target zone at the Louvre meeting (February 1987). ${ }^{9}$ The DSP mean in the table indicates that during this period, the yen appreciated more than 3.5 percent per half month. During subperiods II (June 1987- June 1989) and III (June 1989 - June 1991), the yen fluctuated in the band of 120-160, and the time-series mean is almost zero for both subperiods II and III. In the fourth subperiod, the yen appreciated moderately again, some 40 yen appreciation.

The average expected changes in the yen and their forecast errors suggest that forecasters seem to have been persistent in their mistakes. The magnitude of mistakes in traders' expectations can be seen in the table 2 (the row for FE1) shows that traders in predicting one-month change of the yen, on average, underestimated the yen appreciation by 0.8 percent in the first subperiod, and then overestimated it by 1.2 percent. $^{10}$ In the third subperiod, the size of mistake was reduced to less than 0.5 percent. In the last subperiod, traders again underestimated the yen appreciation by 0.8 percent. However, we have to be cautious in interpreting these biases in forecasts, since standard errors are large.

For subperiod III, forecast errors were the least of the subperiods for all forecast horizons. The numbers are much closer than their compared to corresponding numbers in 
subperiods I and II. After four years of mistakes -- first underestimating appreciation for two years and then overestimating appreciation for two years, market participants seemed to have finally figured out the characteristics of the exchange rate behavior. Alternatively, we may interpret it in that since the variance of $\mathrm{s}$ is much smaller in this period, there was less change for mistakes anyway.

Forecast errors in three-month and six-month forecasts (FE3 and FE6) show more blatant mistakes. In the first subperiod, traders underestimated the three-month yen appreciation by 4.5 percent, and the six-month yen appreciation by more than 10 percent. However, there are overlapping observations for calculating the forecast errors in the "average" here. Hence, this alone should not be taken as statistical evidence of biases. It is fair to conclude that the effect of the Plaza agreement was underestimated by market participants.

\section{Long-run vs Short-run}

Now let us turn to the issue of short-run vs. long-run expectations. During the persistent appreciation phase from 1985 to 1987 , the magnitude of expected changes in three months (SE3) was less than that in one month (SE1). The most striking feature of all is the six-month expectations (SE6), which were on average in the direction of depreciation, resulting in specutacular forecast errors. During the two years, including the post Plaza agreement months, the six month forecasts turned out to be underestimated the yen appreciation by 11 percent on average. Traders, forecasting the future path of the yen, were expecting that a yen appreciation would continue for one month, would start to depreciate from one month to three months and then would decidedly depreciate from three months to six months. During the appreciation phase from 1991 to 1993 , traders were 
expecting a larger appreciation in three months than in one month, and an even larger appreciation in six months than in three months, the exchange rate ex post hardly appreciated.

First, compare the subperiod mean of expected changes for different horizons, SE1(mean), SE3(mean), and SE6(mean), for each subperiods I, II, III, and IV:

$$
\begin{aligned}
& \text { SE1 }<\text { SE3 }<0<\text { SE6 } \\
& 0>\mathrm{SE} 1>\mathrm{SE} 3>\mathrm{SE6} \\
& 0>\mathrm{SE6}>\mathrm{SE} 1>\mathrm{SE} 3 \\
& \mathrm{SE} 1<0<\mathrm{SE} 3<\mathrm{SE6} .
\end{aligned}
$$

The first and fourth subperiod shows a common pattern. Since the yen on average appreciated during these subperiods, the evidence is suggestive of the following scenario (which will be put to a rigorous test in the next section of this paper). In response to an appreciation in weeks prior to a survey date, market participants predicted that the yen would continue to appreciate for the following month but would depreciate in the long run (three to six months) to partially offset the appreciation that had just happened. The former aspect is called a "bandwagon" expectation and the latter a "mean-reversion" expectation.

For subperiod II, the average actual change per month was a 0.05 percent depreciation, while one-month expectations were on average a 1 percent appreciation. Predicting a large appreciation turned out to be a mistake. FE1, FE3, and FE6 show that market participants had on average expected more appreciation than actually occurred. This point is even more striking in three-month and six-month expectations. The table shows expectations of 2.4 percent appreciation in three months and 2.7 percent appreciation in six months. In subperiod II, more and more appreciation was predicted as the horizon lengthened from 
one to three months, and from three to six months. So in this subperiod, a statement of "short-run bandwagon and long-run mean-reversion" does not appear to apply (at least for unconditional means). Since yen appreciation had stopped by 1987 (see small "Change Sum" for subperiod II), expectations of large appreciations in three or six months resulted in large forecast errors. The exchange rate remained in relatively narrow band during this period (see the small "Change Sum" and ", large forecast errors. During subperiod II, expectations caught up with the magnitude of actual rapid appreciation that occurred during subperiod I. Just when the survey participants predicted a sizeable appreciation, the actual appreciation process stalled and sometimes reversed.

In subperiod III, traders were expecting little changes in the yen/dollar rate for all horizons from one month to six months, and the actual change ex post was small. ${ }^{11}$ Although the magnitude of the difference is small, an expected appreciation for six months was less than that for one month, or that for three months. Hence, a phenomenon of "short-run bandwagon and long-run mean-reversion" again emerged in this subperiod. Market participants were predicting that the exchange rate would appreciate more until three months from a survey date, but would turn around sometime between three months and six months from the survey date, so that six months hence, the exchange rate would be close to the level on a survey day itself.

In sum, we observe, in unconditional means of expectations, that in three out of four subperiods, the phenomenon of short-run bandwagon and long-run mean-reversion is present. But, this may not be satisfactory. If a long-run "trend" (independent of actual experiences of exchange rate changes) is forecasted to exist, then unconditional means may reflect just "trends." A more interesting line of investigation is to examine how 
expectations of various horizons respond to changes in the exchange rate. This is pursued in the next section.

\section{Regression Analysis}

Econometric work using survey data of exchange rates have become popular in the past several years. Frankel and Froot (1990a,b) and Ito (1990) found that market participants form bandwagon-type expectations for a short horizon (one-week or one-month) and mean-reversion-type expectations for a long horizon (six-month or one-year).

In the present paper, the former work in the literature is extended so that the possibility of mean-reversion expectations are explicitly modeled using the concept of a long-run equilibrium exchange rate. Since the exchange rate movement as depicted in Figure 1 is known to all market participants, it is natural for the econometrician to model that traders infer the exchange rate behavior as a combination of the short-run bandwagon and the long-run mean-reversion. In order to model explicitly the long-run mean reversion, we will adopt the long-run trend in the preceding section as one of the variable that the expectation is based on. In a strict sense, this trend was not known at the time of expectation formation in a strict sense. However, as argued later, the result is not affected if the current account equilibrium rate is used in place of the log-linear trend. The equilibrium rate was theoretically known after 1980 , if one realized that the exchange rate would have tendency to come back to the equilibrium rate, possibly after a long period of deviation.

As it has been shown in the rational expectation literature, any long-run expectation can be constructed as a compound expectation of successive short-run expectations. When 
this principle is applied to the survey data with different expectation horizons, some care has to be taken as to how many regressors are chosen, or what are the constraints on coefficients of regressors. (See Ito (1990) and Froot and Ito (1989).) ${ }^{12}$

However, neither Ito (1990) nor Froot and Ito (1989) modeled a long-run equilibrium value. In the following, I will estimate a model with different expectation horizons including a variable of the long-run equilibrium to which the exchange rate will return eventually. Theory behind such a specification can be found in Frankel and Froot (1988, 1990).

Now, different responses of expectations of different horizons to a shock in the exchange rate prior to the survey are examined. In particular, the expected change in the exchange rate is regressed on the actual change in the exchange rate prior to the survey date and the deviation from the long-run equilibrium:

$$
\operatorname{SEk}(\mathrm{t})=\mathrm{a}_{\mathbf{k}}+\mathrm{b}_{\mathrm{k}} \operatorname{CHGj}(\mathrm{t})+\mathrm{c}_{\mathrm{k}} \operatorname{DEV}(\mathrm{t})+\mathrm{e}(\mathrm{t}),
$$

where SE $k$ is the expected change revealed from the survey for the horizon of next $\mathrm{k}$ months, $k=1,3,6$, and $e(t)$ is the disturbance term.

CHGj is a measure of the past changes and one of the following three is used in a regression: $\mathrm{CHG}(\mathrm{t})$ is the past 2-week change, and the estimated results with $\mathrm{CHG}(\mathrm{t})$ are presented in Table 3, panel A; CHG1(t) is the past 1-month change, and the estimated results with CHG1(t) are presented in Table 3, panel B; and CHG3(t) is the past 3-month change, and the estimated results with CHG3(t) are presented in Table 3, panel $\mathrm{C}_{.}{ }^{13}$

$\operatorname{DEV}(\mathrm{t})$ is the percentage deviation from the log-linear longrun trend, calculated (interpolated) from the quarterly level of the yen/dollar rate from 1973 to 1993, as depicted in Table 1 and Figure 1 (SEQ3). ${ }^{14}$ When traders form an expectation that the exchange 
rate will eventually revert to the "mean," or a kind of equilibrium, the DEV term becomes important.

Note that equation (2) can be rearranged into the following equation:

$E S(t+k) / S(t)=a k+\left[\left(1-b_{k}-c_{k}\right) * S(t)+b_{k} * S(t-1)+c_{k} S E Q(t)\right] / S(t)+e(t)$

Hence, $b_{k}$ can be interpreted as the coefficient of adaptive expectations. Coefficient $b_{k}$ represents traders' reaction to the recent changes in the exchange rate and coefficient $c_{k}$ represents traders' reaction to the level of the current exchange rate relative to the long-run equilibrium. It is easy to see that the bandwagon expectation corresponds to the case, $b_{k}$ $<0$, and mean-reversion to the equilibrium corresponds to the case, $0<\mathrm{c}_{\mathbf{k}}<1$. Intuition giving this result is as follows. Bandwagon expectations $\left(b_{1}<0\right)$ imply that traders expect an explosive process of the exchange rate. However, as the exchange rate deviates from the equilibrium level, the force to pull back to the equilibrium by $c_{k} D E V(t)$ will become greater. Eventually, the latter, the mean reversion force, will overwhelm the former, namely the bandwagon force. Hence specification (2) encompasses the possibility of the "short-run bandwagon and long-run mean-reversion."

When $c_{k}$ is restricted to be zero, it becomes

$$
\operatorname{SEk}(\mathrm{t})=\mathrm{a}_{\mathbf{k}}+\mathrm{b}_{\mathbf{k}} \operatorname{CHGj}(\mathrm{t})+\mathrm{e}(\mathrm{t}),
$$

which is a familiar specification in the literature. Estimated coefficients for sepcification (2") are shown in Table 3, Panel A-1, B-1, and C-1. General results of specification (2) are reported in Table 3, A-2, B-2, and C-2. The specification of (2") likely suffers from inconsistent expectations in the sense of Ito (1990) and Froot and Ito (1988): the finding $\mathrm{b}_{1}<0<\mathrm{b}_{3}<\mathrm{b}_{6}$, such as the case in subperiod I, is usually interpreted as an evidence of "short-run bandwagon and long-run mean-reversion" as in Frankel and Froot (1987b). But, 
this is inconsistent, because compounding one-month expectations into a six-month expectation (using iterated projections in the rational expectation literature) cannot produce the expectation of the opposite sign..$^{15}$

*** Table 3, Panel A, B, and C about here ***

One of the robust findings in Table 3 , in all panels and all subperiods, is

$$
b_{1}<b_{3}<b_{6}
$$

which can be interpreted as an evidence for short-run bandwagon and long-run meanreversion expectations. The estimates of $b_{6}$ in all subperiods, are positive and statistically significantly. Market participants expect that any large change (from $t-1$ to $t$ ) will be reversed partially in the long run (six months), a common tendency. This is strong evidence for the "mean-reversion" property in the long-run. The $b_{1}$ coefficient is negative in all subperiods, but it is statistically significant only in subperiod II, using CHG and CHG1, and is statistically significant for subperiods I, II, and III if CHG3 is used. The coefficient $b_{3}$ seems to be close to zero. Whether one defines past exchange rate changes as two-week, one-month, or three-month changes does not seem to affect qualitative aspect of results.

The signs and sizes of $c_{k}, k=1,3,6$, are not robust with respect to subperiods. Some of them, such as $c_{1}$ and $c_{3}$ in subperiods I and III, are negative, contrary to our theoretical prediction in that mean-reversion will be forced by $c_{k}>0$.

In summary, responses of short-horizon and long-horizon expectations with respect to a recent change in the exchange rate (b coefficients) are in the same direction with the past changes in the short horizon $\left(b_{1}<0\right)$ but the opposite direction in the long horizon $\left(b_{6}>\right.$ 
0). Put differently, the phenomenon of short-run bandwagon and long-run mean-reversion, in terms of $\mathrm{b}$ coefficients, is confirmed in Table 3.

Adding the deviation from the equilibrium exchange rate as a regressor should pick up a force pulling back toward the equilibrium once the exchange rate deviates from the equilibrium. The sign of coefficient $c$ on the deviation is not robust with respect to subperiods of estimation. Note that $\mathrm{c}_{6}$ is significantly positive in subperiods I, II, and IV, and not significant in subperiod III, which is consistent with the mean-reversion property. However, $c_{1}$ and $c_{3}$ are negative in subperiods I and III, yielding a puzzle that traders expected an explosive process of the exchange rate: the farther the exchange rate is away from the equilibrium, the more probable will the exchange rate deviate away from the equilibrium.

Recall that coefficient $\mathrm{c}$ in the true process does show the mean reversion property (c $>0$ ) as presented in Table 1, which roughly corresponds to Table 3, Panel C-2, subpanel of SE3, in terms of regressors. The difference in coefficients of Table 1 and Table 3 (C-2, SE3), such as the sign of coefficient $c$, can be regarded as the deviation of expectations from the true process, suggesting traders' irrational expectations: traders were unaware of the force toward the equilibrium, and made systematic errors on the mean-reversion force. Even when the exchange rate deviated from the equilibrium, traders underestimated the probability of the exchange rate crashing toward the equilibrium.

\section{Further Regressions}

In this section, more variables which might affect expectation formations are added on the right hand side. If expectations formation is of the adaptive type which corrects for 
past forecast errors, then the past forecast errors should be one of the explanatory variables. Forecast errors of the $\mathrm{k}$-month forecasts revealed at $\mathrm{t}$ are defined as

$$
\operatorname{FE} k(t)=100 *(E S(t-2 k, 2 k)-S(t)) / S(t)
$$

Another variable which is likely to be relevant in making a forecast is the forward premium:

$$
\mathrm{FO} k(\mathrm{t})=100 *(\mathrm{FO} k(\mathrm{t})-\mathrm{S}(\mathrm{t})) / \mathrm{S}(\mathrm{t})
$$

Hence, the equation for forecast formations is now specified as follows:

$\operatorname{SEk}(\mathrm{t})=\mathrm{a}_{\mathbf{k}}+\mathrm{b}_{\mathbf{k}} \operatorname{CHGl}(\mathrm{t})+\mathrm{c}_{\mathbf{k}} \operatorname{FEk}(\mathrm{t})+\mathrm{d}_{\mathbf{k}} \mathrm{FO} k(\mathrm{t})+\mathrm{e}(\mathrm{t})$

where $\mathrm{k}=1,3,6$, and $\mathrm{e}(\mathrm{t})$ is the disturbance term.

Note that each variable in equation (3) can be rearranged as the weighted average of various factors, just the same way as in (2'). A positive coefficient implies that the variable tends to pull the spot rate toward the level of that variable (relative to the spot rate at $\mathrm{t}-1$ ), while a negative coefficient implies that the variable tends to push away the spot rate from that variable (relative to the spot rate of $\mathrm{t}-1$ ).

Results of regression (3) are shown in Table 4. A most notable result is that, for the 1-month forecast equations, the coefficient on forecast errors is positive and significant, implying that market participants revise the forecast so that given the forecast errors, the future spot rate will reverse toward the level that traders expected today's level would be one month ago. Put differently, traders are persistent in their expectation of what the exchange rate would be. The forward premium, in general, does not have a significant . coefficient.

*** insert Table 4 about here 
The "short-run bandwagon and long-run pattern in b coefficients, $b_{1}<b_{3}<b_{6}$ found in Table 3 is again present in Table 4 and the significance has improved. The pattern seems to be robust with respect to adding other regressors.

By examining Table 4, we also note that market participants use different kinds of information for different times.

Lastly, the deviation from the longrun equilibrium is added:

$$
\operatorname{SEk}(\mathrm{t})=\mathrm{a}_{\mathrm{k}}+\mathrm{b}_{\mathrm{k}} \operatorname{CHG} 1(\mathrm{t})+\mathrm{c}_{\mathrm{k}} \operatorname{FE} k(\mathrm{t})+\mathrm{d}_{\mathrm{k}} \operatorname{FO}(\mathrm{t})+\mathrm{g}_{\mathrm{k}} \operatorname{DEV}(\mathrm{t})+\mathrm{e}(\mathrm{t})
$$

in order to see whether results in Table 3, panel B-2 is robust with respect to adding forecast errors and forward premium on the right hand side of the regression.

Results of estimation are shown in Table 5. First, the pattern of the $b$ coefficient, $b_{1}$ $<b_{3}<b_{6} ; b_{1}<0$, and $b_{6}>0$, is again confirmed in this specification. Second, the sign of the coefficient on DEV, the deviation from the equilibrium exchange rate, is not robust. As was the case in Table 3, the coefficient on DEV is negative and significant in the third subperiod, while it is positive and significant in the second subperiod. This shows that traders' have not been consistent over time in extracting information from the deviation variable. The evidence suggests that traders were not sure whether the exchange rate reverts to the long-run mean (equilibrium), or were not sure where the equilibrium was. *** insert Table 5 about here ***

In summary, the expectation formation formula seem to be time-varying, as indicated by widely different coefficient values on various regressors in different subperiods. However, the pattern of the coefficients on the recent exchange rate changes for expectations of different horizons show some support to a hypothesis of "short-run bandwagon and long-run mean reversion" is robust with respect to various specifications. 


\section{Concluding Remarks}

In this paper, the phenomenon of "short-run bandwagon and long-run mean-reverting expectation" was investigated with survey data for eight years. First, we have established that in quarterly data from 1973 to 1993 such a phenomenon exists in the actual exchange rate dynamics. Once the exchange rate deviates from the long-run equilibrium it continues to deviate in the short-run, but eventually the force will pull it back to the long-run equilibrium overcomes the bandwagon. Second, we investigated how traders' expectations for different horizons revealed in the survey data. Coefficients in regressions of expectation formation show the "short-run bandwagon and long-run mean-reversion" property that traders expect that, for the near future, the exchange rate will continue to move in the direction of the changes in the recent past, but that the exchange will move back where it came in the longrun. In order to give an explicit measure of an equilibrium level which the exchange rate return to, I constructed the equilibrium rate as a log-linear trend from 1973 to 1993 . Deviations from the estimated equilibrium is defined and used as one of the regressors in equations of expectation formations. Regressions did not produce a robust estimate for the deviation from the equilibrium. Given that the history of the yen/dollar exchange rate fluctuations in the past two decades shows the mean reversion property, a lack of robust coefficients on a variable of deviation from equilibrium suggests traders' failure in taking into account the mean-reversion property.

Although this paper contributes to the literature of expectation formation, it does leave some questions unanswered. Traders' expectations formation seems to change over time. Although it is clear from past behavior that the yen/dollar exchange rate fluctuates around a trend, it is unclear whether traders explicit consider the possibility of mean 
reversion to the equilibrium. It is left for future research to model a better measure of the longrun equilibrium or the deviation from the equilibrium. 


\section{References}

Cavaglia, Stefano; Willem F. C. Verschoor; and Christian C. P. Wolff, (1993a).

"Further Evidence on Exchange Rate Expectation," Journal of International Money and Finance, vol. 12: 78-98.

Cavaglia, Stefano; Willem F. C. Verschoor; and Christian C. P. Wolff, (1993b).

"Asian Exchange Rate Expectation," Journal of the Japanese and International Economies vol. 7 , no. 1 , March: 57-77.

Dominguez, Kathryn (1986). "Are Foreign Exchange Forecasts Rational? New Evidence from Survey Data," Economics Letters, vol. 21, 277-181.

Engel, Charles and James D. Hamilton, (1990). "Long Swings in the Dollar: Are They in the Data and Do Markets Know It?" American Economic Review, September: 689-713.

Frankel, J. and K. Froot (1987a) "Using Survey Data to Test Standard Propositions Regarding Exchange Rate Expectations," American Economic Review, vol. 77, 133-153.

Frankel, J. and K. Froot (1987b) "Short-Term and Long-term Expectations of the Yen/Dollar Exchange Rate: Evidence from Survey Data" Journal of the Japanese and International Economies, vol. 1, 249-274.

Frankel, Jeffrey and Kenneth Froot (1988), "Chartists, Fundamentalists, and the Demand for Dollars," in Tony Courakis and Mark Taylor, eds., Policy Issues for Interdependent Economies, London: Macmillan 1988.

Froot, Kenneth and Jeffrey Frankel (1990). "Chartists, Fundamentalists, and Trading in the Foreign Exchange Market," American Economic Review, 80: 181-185. 
Froot Kenneth and Takatoshi Ito (1989). "On the Consistency of Short-run and Long-run Exchange Rate Expectations" Journal of International Finance and Money, vol. 8, 487-510.

Ito, Takatoshi (1987). "The Intra-Daily Exchange Rate Dynamics and Monetary Policies after the G5 Agreement," Journal of the Japanese and International Economies, vol. 1, 1987: 275-298.

Ito, Takatoshi (1989). "Was There a Target Zone?" in Japan Center for International Finance (ed.), JCIF Policy Study Series, no.14.

Ito, Takatoshi (1990). "Foreign Exchange Rate Expectations: Micro Survey Data," American Economic Review, vol. 80, June: 434-449.

Sargent, Thomas (1987). Macroeconomic Theory, second edition, New York: Academic Press.

Takagi, Shinji (1991), "Exchange Rate Expectations: · A Survey of Survey Studies," International Monetary Fund Staff Papers, vol 38, June: 156-183. 
Notes:

1. Cavaglia, Verschoor, and Wolff(1993a, 1993b) extended the model to Asian currencies and more recent data.

2. The quarterly exchange rate is defined as an average over a quarter of the daily closing rates in Tokyo.

3. The logarithm of the exchange rate from 1973:1 to $1993: 2$ is regressed on constant and time, and then the exponential of the fitted value is shown in the graph. Implicitly, I am assuming that the exchange rate is mean reverting in the long run. However, if there is a unit root, the coeffient estimates in the above-mentioned regression is not reliable. The direct unit root test in the lower frequencies is not possible for the lack of long observations.

4. For 1973:2, the average of exchange rates of 1972:4, 1973:1, 1973:2, and 1973:3 is used, while for 1979:2, the average of exchange rates of 1978:4, $1979: 1,1979: 2$, and $1979: 3$ is used.

5. Respondents are foreign exchange experts in 44 companies: 15 banks and brokers, 4 securities houses, 6 trading companies, 9 export-oriented companies, 5 life insurance companies, and 5 import-oriented companies. They are asked to forecast the future yen/dollar exchange rate for 1-month, 3-months and 6-months from the survey date. The surveys have very few "holes." (There are a few missing observations for individual companies.) Hence, essentially, this can be regarded as a panel data. However, in this paper, we use only the average of the 44 participants as the representative expectations of the market. For biases based on the types of industries, see Ito $(1990)$.

6. Surveys were not taken in mid-August in 1990, 1991, and 1992, and the end of December 1991 and 1992, to accommodate holiday seasons.

7. For the entire period and the first period, the last period of the preceding subperiod is defined as the date that the survey would have been taken if the survey had existed before the mid-May 1985.

8. A large yen appreciation, partially aided by the Plaza agreement (September 22, 1985), took place from 1985 to 1987. Starting from June 1985, the yen appreciated from 250 to 160 in twelve months, and then from 160 to 140 in the following 12 months. See Ito (1987)(1989) for description of the episode of a sharp appreciation and the forces behind it.

9. See Ito (1987) for analysis of the intradaily yen/dollar exchange rate movement after the Plaza agreement. It is widely believed that the Louvre. agreement in February 1987 set up a target zone of the major exchange rates. There was a lot of talk and speculation about the exact range of target zone in 1987 and 1988. See Ito (1989). However, the target zone for the yen/dollar exchange rate has not been mentioned as an issue in the public press since 1989. 
10. Expectations were spectacularly wrong around the Plaza agreement. On September 11 (before the Plaza agreement), the spot rate was 244 yen/dollar, while the range of 1-month expectations of 44 market participants was from 235 yen to 249 yen, with an average of 242. (The correct rate turned out to be 216.2.) No one predicted the sharp appreciation following the plaza agreement. On September 25 (after the Plaza agreement), the spot rate was 229 yen/dollar, while the range of expectations was from 210 to 235 , with an average of 227 . (The correct rate turned out to be 211.6. )

11. This does not mean that subperiod III was a "calm" period. In fact, subperiod III was the most "volatile" among the three subperiods, if the volatility is measured in standard deviation of half-month changes. This may be surprising to the informed reader who remembers a large change immediately after the Plaza agreement in subperiod I. During two-week period that includes the Plaza agreement, the yen appreciated from 244 yen to 229 yen, about a 15 percent appreciation, from September 11 to september 25. From September 25 to october 16 in 1990, the yen appreciated form 136.7 to 128 . This change is larger in the percentage term.

12. First, if there is only a single regressor (say, the past actual changes in the exchange rate) on the right hand side for expectation formations for different horizons, then the model implies that an expected change in the long horizon must be proportional to an expected change in the short horizon, which is not the case in "short-run bandwagon and long-run mean reversion" type expectations. Second, if it is modeled to include several of past changes in the exchange rate, then a set of cross-equation constraints has to be satisfied in equations with expectations of different horizons on the left-hand side but with the same regressors. When such cross-equation constraints are satisfied, short-run and long-run expectations are called "consistent." Ito (1990) and Froot and Ito (1989) investigated consistency of such expectation formations from survey data.

13. Noting that one period in our sample corresponds to the survey interval, usually two weeks, followings are the definitions of variables:

$\operatorname{CHG}(t)=100 *(\operatorname{SPOT}(t-1)-\operatorname{SPOT}(t)) / \operatorname{SPOT}(t)$

$\operatorname{CHG} 1(t)=100 *(\operatorname{SPOT}(t-2)-\operatorname{SPOT}(t)) / \operatorname{SPOT}(t)$

$\operatorname{CHG} 3(t)=100 *(\operatorname{SPOT}(t-6)-\operatorname{SPOT}(t)) / \operatorname{SPOT}(t)$

14. DEV is defined as

$\mathrm{DEV}=100 *(\operatorname{SEQ} 3(t)-\operatorname{SPOT}(t)) / \operatorname{SPOT}(t)$.

One may object to use this variable, since traders in 1985 would not be able to calculate the log-linear trend fitted for the data from 1973 to 1993. First, since this is fitted to a long period starting 1973, adding one or two observations do not change the trend much. However, it is well taken that back in 1985, the trend would have looked rather different. Second, alternatively we may use the alternative definition of longrun equilibrium discussed earlier in this paper. When a long-run equilibrium is defined as the exchange rate when the Japanese current account was approximately balanced, namely 1973 and 1979, the extrapolated equilibrium was depicted as SEQ3 in Figure 1. Note that the difference between $S E Q 2$ and $S E Q 3$ is almost constant for the sample period. From this, it is easy to see that substituting SEQ3 by SEQ2 will hardly change the regression results, which indeed turns out to be the case (although they are not reported). Since SEQ2 is defined with data points in 1973 and 1979, 
the above criticism of using SEQ3 would not apply. Traders in 1985 know exact values of SEQ2.

15. See, for example, sargent (1987, p.235) for iterated projections. 
Table 1: Quarterly Exchange Rate Movement

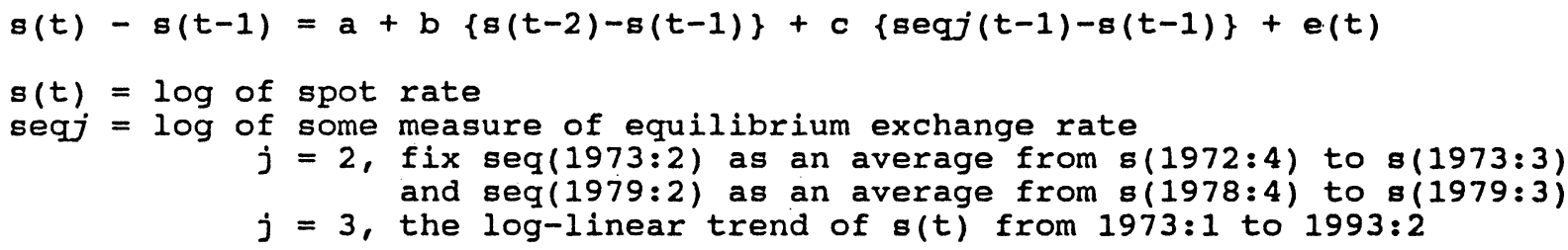

Sample: 1973:1 - 1993:2, quarterly

Estimated by oLs

\begin{tabular}{|c|c|c|c|c|}
\hline specif. & $a^{a}(t-s t a t)$ & b $(t-s t a t)$ & $(t-s t a t)$ & $\begin{array}{l}R \text { bar } \mathbf{s q} \\
\text { DurbinWatson }\end{array}$ \\
\hline (1) & -- & $\begin{array}{l}-0.367 \\
(-3.466)\end{array}$ & -- & $\begin{array}{l}\text { Rsq }=0.092 \\
D W=1.900\end{array}$ \\
\hline$(2)$, seq2 & -- & $\begin{array}{l}-0.352 \\
(-3.452) *\end{array}$ & $\begin{array}{l}0.068 \\
(2.758) * \\
\end{array}$ & $\begin{array}{l}\mathrm{Rsq}=0.162 \\
\mathrm{DW}=1.919\end{array}$ \\
\hline$(2), \operatorname{seq} 3$ & -- & $\begin{array}{l}-0.412 \\
(-3.980) *\end{array}$ & $\begin{array}{l}0.105 \\
(2.651) * \\
\end{array}$ & $\begin{array}{l}\text { Rsq }=0.157 \\
\mathrm{DW}=1.950\end{array}$ \\
\hline (3) & $\begin{array}{l}-0.007 \\
(-1.323) \\
\end{array}$ & $\begin{array}{l}-0.338 \\
(-3.138) * \\
\end{array}$ & -- & $\begin{array}{l}\text { Rsq }=0.101 \\
\mathrm{DW}=1.891\end{array}$ \\
\hline$(4)$, seq2 & $\begin{array}{l}0.010 \\
(1.204) \\
\end{array}$ & $\begin{array}{l}-0.384 \\
(-3.654) * \\
\end{array}$ & $\begin{array}{l}0.105 \\
(2.685) * \\
\end{array}$ & $\begin{array}{l}\text { Rsq }=0.167 \\
D W=1.945\end{array}$ \\
\hline$(4), \operatorname{seq} 3$ & $\begin{array}{c}-0.007 \\
(-1.215) \\
\end{array}$ & $\begin{array}{l}-0.385 \\
(-3.646) * \\
\end{array}$ & $\begin{array}{l}0.102 \\
(2.582) * \\
\end{array}$ & $\begin{array}{l}\mathrm{Rsq}=0.162 \\
\mathrm{DW}=1.941\end{array}$ \\
\hline
\end{tabular}


Table 2: Survey Data Summary

$\operatorname{sEk}(t)=100 *(\operatorname{ESk}(t+2 k)-S(t)) / S(t), \quad$ Expected Change in k-month (z)

DSP $\quad=100 *(s(t)-s(t-1)) / s(t-1), \quad$ Actual Change in past half month (8)

$\operatorname{FEk}(t)=100 *(\operatorname{ES} k(t+2 k)-S(t+2 k)) / S(t)$, Forecast Error in $k$-month expectation (8)

where $S(t)$ is the spot rate of Yen/\$ (Tokyo closing of the survey day); $E S(t+2 k$ ) is the survey expectation of the $k$-month ahead forecast. Total sum of change (row of Total Sum) is defined by the change of the yen/\$ rate during the corresponding sample period in the unit of yen/dollar.

\begin{tabular}{|c|c|c|c|c|c|}
\hline & $\begin{array}{l}\text { Whole } \\
1985-1993\end{array}$ & $\begin{array}{c}I \\
1985-1987\end{array}$ & $\begin{array}{c}\text { II } \\
1987-1989\end{array}$ & $\begin{array}{c}\text { III } \\
1989-1991\end{array}$ & $\begin{array}{c}\text { IV } \\
1991-1993\end{array}$ \\
\hline \# obs & 192 & 48 & 48 & 48 & 48 \\
\hline $\begin{array}{c}\text { SE1, Mean } \\
\text { stdDev }\end{array}$ & $\begin{array}{r}-0.820 \\
0.833 \\
\end{array}$ & $\begin{array}{r}-1.413 \\
0.607 \\
\end{array}$ & $\begin{array}{r}-1.090 \\
0.680 \\
\end{array}$ & $\begin{array}{r}-0.542 \\
0.830 \\
\end{array}$ & $\begin{array}{r}-0.235 \\
0.664 \\
\end{array}$ \\
\hline $\begin{array}{c}\text { SE3, Mean } \\
\text { stdDev }\end{array}$ & $\begin{array}{r}-1.001 \\
1.422 \\
\end{array}$ & $\begin{array}{r}-1.321 \\
1.242 \\
\end{array}$ & $\begin{array}{r}-2.386 \\
0.617 \\
\end{array}$ & $\begin{array}{r}-0.743 \\
1.236 \\
\end{array}$ & $\begin{array}{l}0.445 \\
0.709 \\
\end{array}$ \\
\hline $\begin{array}{l}\text { SE6, Mean } \\
\text { stdDev }\end{array}$ & $\begin{array}{r}-0.486 \\
2.259 \\
\end{array}$ & $\begin{array}{l}0.130 \\
2.124 \\
\end{array}$ & $\begin{array}{r}-2.677 \\
1.674 \\
\end{array}$ & $\begin{array}{r}-0.360 \\
1.800 \\
\end{array}$ & $\begin{array}{l}0.964 \\
1.652 \\
\end{array}$ \\
\hline $\begin{array}{l}\text { DSP, Mean } \\
\text { stdDev }\end{array}$ & $\begin{array}{r}-0.482 \\
2.283\end{array}$ & $\begin{array}{r}-3.670 \\
0.467\end{array}$ & $\begin{array}{r}-0.070 \\
2.154\end{array}$ & $\begin{array}{l}0.031 \\
2.555\end{array}$ & $\begin{array}{r}-0.655 \\
1.881 \\
\end{array}$ \\
\hline Change Sum & -150.15 & -111.57 & -3.13 & 4.35 & -39.80 \\
\hline $\begin{array}{c}\text { FE1, Mean } \\
\text { stdDev } \\
\# \text { Obs } \\
\end{array}$ & $\begin{array}{l}-0.005 \\
3.610 \\
190 \\
\end{array}$ & $\begin{array}{c}0.846 \\
3.672 \\
48 \\
\end{array}$ & $\begin{array}{c}-1.247 \\
3.697 \\
48 \\
\end{array}$ & $\begin{array}{c}-0.439 \\
3.734 \\
48 \\
\end{array}$ & $\begin{array}{l}0.855 \\
2.905 \\
46\end{array}$ \\
\hline $\begin{array}{c}\text { FE3, Mean } \\
\text { stdDev } \\
\# \text { Obs } \\
\end{array}$ & $\begin{array}{l}1.266 \\
6.309 \\
186 \\
\end{array}$ & $\begin{array}{c}4.634 \\
5.790 \\
48\end{array}$ & $\begin{array}{c}-2.212 \\
6.405 \\
48 \\
\end{array}$ & $\begin{array}{c}-0.655 \\
5.782 \\
48\end{array}$ & $\begin{array}{c}3.588 \\
4.303 \\
42\end{array}$ \\
\hline $\begin{array}{c}\text { FE6, Mean } \\
\text { stdDev } \\
\# \text { Obs }\end{array}$ & $\begin{array}{l}3.555 \\
9.338 \\
180\end{array}$ & $\begin{array}{c}11.085 \\
7.867 \\
48\end{array}$ & $\begin{array}{c}-2.855 \\
8.553 \\
48\end{array}$ & $\begin{array}{l}0.755 \\
8.277 \\
48\end{array}$ & $\begin{array}{c}5.793 \\
4.750 \\
36\end{array}$ \\
\hline
\end{tabular}


Table 3: Expectation Formation, specification I (Extrapolative Expectation) Panel A (2-week change as a regressor):

$\operatorname{SEk}(t)=a_{k}+b_{k} \operatorname{CHG}(t)+c_{k} \operatorname{DEV}(t)+e(t)$, where $\operatorname{CHG}(t)=100 *(\operatorname{SPOT}(t-1)-\operatorname{SPOT}(t)) / \operatorname{SPOT}(t)$ is the 2 -wk change; and $k=1,3,6$.

Panel A-1: and $c_{k}=0$ imposed:

Coefficients and (t-statistics)

\begin{tabular}{|c|c|c|c|c|c|c|}
\hline & & $\begin{array}{l}\text { Whole } \\
1985-1993\end{array}$ & $\begin{array}{c}I \\
1985-1987 \\
\end{array}$ & $\begin{array}{c}\text { II } \\
1987-1989 \\
\end{array}$ & $\begin{array}{c}\text { III } \\
1989-1991 \\
\end{array}$ & $\begin{array}{c}\text { IV } \\
1991-1993 \\
\end{array}$ \\
\hline LHS & Coef & $\# O b s=144$ & $\#$ Obs $=48$ & $\#$ Obs $=48$ & $\#$ Obs $=48$ & $\# \mathrm{Obs}=48$ \\
\hline \multirow[t]{2}{*}{ SE 1} & $a_{1}$ & $\begin{array}{l}-0.787 \\
(-8.435) * \\
\end{array}$ & $\begin{array}{c}-1.376 \\
(-9.851) *\end{array}$ & $\begin{array}{l}-1.080 \\
(-8.696) *\end{array}$ & $\begin{array}{c}-0.542 \\
(-2.914) *\end{array}$ & $\begin{array}{c}-0.243 \\
(-1.713) \\
\end{array}$ \\
\hline & $b_{1}$ & $\begin{array}{l}-0.066 \\
(-2.218) * \\
\end{array}$ & $\begin{array}{l}-0.030 \\
(-0.812) \\
\end{array}$ & $\begin{array}{r}-0.137 \\
(-3.613) * \\
\end{array}$ & $\begin{array}{l}-0.045 \\
(-0.788) \\
\end{array}$ & $\begin{array}{l}0.013 \\
(0.234) \\
\end{array}$ \\
\hline \multirow[t]{2}{*}{ SE3 } & $a_{3}$ & $\begin{array}{c}-1.044 \\
(-3.712) \star\end{array}$ & $\begin{array}{l}-1.477 \\
(-4.880)\end{array}$ & $\begin{array}{l}-2.385 \\
(-14.15) *\end{array}$ & $\begin{array}{l}-0.743 \\
(-1.727) \\
\end{array}$ & $\begin{array}{c}0.384 \\
(1.800) \\
\end{array}$ \\
\hline & $\mathrm{b}_{3}$ & $\begin{array}{l}0.086 \\
(1.794) \\
\end{array}$ & $\begin{array}{l}0.126 \\
(3.921) * \\
\end{array}$ & $\begin{array}{l}-0.010 \\
(-0.228) \\
\end{array}$ & $\begin{array}{c}0.059 \\
(1.242) \\
\end{array}$ & $\begin{array}{c}0.091 \\
(2.006) * \\
\end{array}$ \\
\hline \multirow[t]{2}{*}{ SE6 } & $a_{6}$ & $\begin{array}{c}-0.654 \\
(-1.338) \\
\end{array}$ & $\begin{array}{l}-0.279 \\
(-0.780) \\
\end{array}$ & $\begin{array}{c}-2.696 \\
(-47.41) \star\end{array}$ & $\begin{array}{l}-0.359 \\
(-0.539) \\
\end{array}$ & $\begin{array}{r}0.728 \\
(1.552) \\
\end{array}$ \\
\hline & $b_{6}$ & $\begin{array}{l}0.340 \\
(4.939) *\end{array}$ & $\begin{array}{l}0.330 \\
(4.415) *\end{array}$ & $\begin{array}{c}0.277 \\
(4.376) \star\end{array}$ & $\begin{array}{c}0.196 \\
(3.322)^{\star}\end{array}$ & $\begin{array}{c}0.354 \\
(7.420) *\end{array}$ \\
\hline
\end{tabular}

Panel A-2 (DEV included), Coefficients and (t-statistics)

\begin{tabular}{|c|c|c|c|c|c|c|}
\hline & & $\begin{array}{l}\text { Whole } \\
1985-1993\end{array}$ & $\begin{array}{c}I \\
1985-1987\end{array}$ & $\begin{array}{c}\text { II } \\
1987-1989\end{array}$ & $\begin{array}{c}\text { III } \\
1989-1991\end{array}$ & $\begin{array}{c}\text { IV } \\
1991-1993\end{array}$ \\
\hline LHS & Coef & $\#$ OBS $=192$ & $\#$ OBS $=48$ & \#OBS $=48$ & \#OBS $=48$ & $\# O B S=48$ \\
\hline \multirow[t]{3}{*}{ SE 1} & $a_{1}$ & $\begin{array}{l}-0.705 \\
(-6.883) * \\
\end{array}$ & $\begin{array}{l}-1.414 \\
(-11.31) * \\
\end{array}$ & $\begin{array}{r}-0.215 \\
(0.600) \\
\end{array}$ & $\begin{array}{l}-0.413 \\
(-3.066) \star \\
\end{array}$ & $\begin{array}{c}-0.217 \\
(-1.235) \\
\end{array}$ \\
\hline & $b_{1}$ & $\begin{array}{l}-0.066 \\
(-2.260) \star\end{array}$ & $\begin{array}{l}-0.033 \\
(-0.957) \\
\end{array}$ & $\begin{array}{l}-0.104 \\
(-2.501) \star\end{array}$ & $\begin{array}{l}-0.011 \\
(-0.192) \star\end{array}$ & $\begin{array}{l}0.019 \\
(0.289) \\
\end{array}$ \\
\hline & $c_{1}$ & $\begin{array}{c}-0.014 \\
(-2.090) *\end{array}$ & $\begin{array}{l}-0.017 \\
(-2.570) *\end{array}$ & $\begin{array}{c}-0.045 \\
(-2.124) \star\end{array}$ & $\begin{array}{l}-0.084 \\
(-2.573) \star\end{array}$ & $\begin{array}{l}-0.006 \\
(-0.227)\end{array}$ \\
\hline \multirow[t]{3}{*}{ SE3 } & $a_{3}$ & $\begin{array}{l}-0.806 \\
(-2.935) *\end{array}$ & $\begin{array}{l}-1.506 \\
(-4.990) \star\end{array}$ & $\begin{array}{l}-3.082 \\
(-8.750)\end{array}$ & $\begin{array}{c}-0.478 \\
(-2.063) \\
\end{array}$ & $\left(\begin{array}{l}0.200 \\
0.710) \\
\end{array}\right.$ \\
\hline & $\mathrm{b}_{3}$ & $\begin{array}{c}0.085 \\
(1.838) \\
\end{array}$ & $\begin{array}{c}0.123 \\
(3.742) \star \\
\end{array}$ & $\begin{array}{l}-0.036 \\
(-1.014) \\
\end{array}$ & $\begin{array}{c}0.128 \\
(2.578) * \\
\end{array}$ & $\begin{array}{r}0.048 \\
(1.653) \\
\end{array}$ \\
\hline & $c_{3}$ & $\begin{array}{l}-0.040 \\
(-2.124) * \\
\end{array}$ & $\begin{array}{l}-0.013 \\
(-0.814) * \\
\end{array}$ & $\begin{array}{l}0.035 \\
(1.825) \\
\end{array}$ & $\begin{array}{c}-0.172 \\
(-4.288) \star\end{array}$ & $\begin{array}{l}0.040 \\
(1.633) \\
\end{array}$ \\
\hline \multirow[t]{3}{*}{ SE6 } & $a_{6}$ & $\begin{array}{r}-0.475 \\
(-1.215) \\
\end{array}$ & $\begin{array}{l}-0.219 \\
(-0.495) \\
\end{array}$ & $\begin{array}{l}-7.097 \\
(-8.341) *\end{array}$ & $\begin{array}{l}-0.361 \\
(-0.714)\end{array}$ & $\begin{array}{l}-0.080 \\
(-0.112) \\
\end{array}$ \\
\hline & $b_{6}$ & $\begin{array}{c}0.339 \\
(5.121)^{*} \\
\end{array}$ & $\begin{array}{c}0.334 \\
(4.739)^{\star} \\
\end{array}$ & $\begin{array}{l}0.109 \\
(1.908) \\
\end{array}$ & $\begin{array}{l}0.196 \\
(1.889) \\
\end{array}$ & $\begin{array}{c}0.165 \\
(2.408) * \\
\end{array}$ \\
\hline & $c_{6}$ & $\begin{array}{l}-0.029 \\
(-1.121) \\
\end{array}$ & $\begin{array}{l}0.028 \\
(1.298) * \\
\end{array}$ & $\begin{array}{l}0.227 \\
(8.170) * \\
\end{array}$ & $\begin{array}{l}0.001 \\
(0.007) \\
\end{array}$ & $\begin{array}{l}0.174 \\
(3.159)^{*} \\
\end{array}$ \\
\hline
\end{tabular}


Table 3,

Panel B (1-month change as a regressor):

$\operatorname{sEk}(t)=a_{k}+b_{k} \operatorname{CHGl}(t)+c_{k} \operatorname{DEV}(t)+e(t)$,

where $\operatorname{CHGI}(t)=100 *(\operatorname{SPOT}(t-2)-\operatorname{SPOT}(t)) / \operatorname{SPOT}(t)$ is the 2 -wk change; and $k=1,3,6$.

Panel B-1: and $c_{k}=0$ imposed, Coefficients and (t-statistics)"

\begin{tabular}{|c|c|c|c|c|c|c|}
\hline & & $\begin{array}{l}\text { Whole } \\
1985-1993\end{array}$ & $\begin{array}{c}I \\
1985-1987\end{array}$ & $\begin{array}{c}\text { II } \\
1987-1989\end{array}$ & $\begin{array}{c}\text { III } \\
1989-1991 \\
\end{array}$ & $\begin{array}{c}\text { IV } \\
1991-1993\end{array}$ \\
\hline LHS & Coef & $\# \quad O b s=144$ & $\#$ Obs $=48$ & $\#$ Obs $=48$ & $\# \mathrm{Obs}=48$ & $\# \mathrm{Obs}=48$ \\
\hline \multirow[t]{2}{*}{$\mathrm{SE} 1$} & $a_{1}$ & $\begin{array}{l}-0.754 \\
(-8.075) * \\
\end{array}$ & $\begin{array}{c}-1.404 \\
(-9.759) * \\
\end{array}$ & $\begin{array}{c}-1.066 \\
(-9.291) \star \\
\end{array}$ & $\begin{array}{l}-0.543 \\
(-3.054) *\end{array}$ & $\begin{array}{c}-0.211 \\
(-1.524) \\
\end{array}$ \\
\hline & $\mathrm{b}_{1}$ & $\begin{array}{l}-0.069 \\
(-3.360) *\end{array}$ & $\begin{array}{l}-0.020 \\
(-0.784) \\
\end{array}$ & $\begin{array}{c}-0.114 \\
(-4.116) \star\end{array}$ & $\begin{array}{l}-0.065 \\
(-1.638) \\
\end{array}$ & $\begin{array}{l}-0.012 \\
(-0.504) \\
\end{array}$ \\
\hline \multirow[t]{2}{*}{ SE3 } & $a_{3}$ & $\begin{array}{c}-1.061 \\
(-3.634) *\end{array}$ & $\begin{array}{l}-1.689 \\
(-5.410) \star\end{array}$ & $\begin{array}{l}-2.386 \\
(-14.08) *\end{array}$ & $\begin{array}{c}-0.743 \\
(-1.753) \\
\end{array}$ & $\begin{array}{c}0.402 \\
(1.900) \\
\end{array}$ \\
\hline & $\mathrm{b}_{3}$ & $\begin{array}{l}0.053 \\
(\quad 1.296) \\
\end{array}$ & $\begin{array}{l}0.125 \\
(4.119) * \\
\end{array}$ & $\begin{array}{l}-0.000 \\
(-0.019)\end{array}$ & $\begin{array}{l}0.006 \\
(0.132) \\
\end{array}$ & $\begin{array}{c}0.033 \\
(0.565) \\
\end{array}$ \\
\hline \multirow[t]{2}{*}{ SE6 } & $a_{6}$ & $\begin{array}{c}-0.756 \\
(-1.572) \\
\end{array}$ & $\begin{array}{l}-0.552 \\
(-2.209) *\end{array}$ & $\begin{array}{r}-2.724 \\
(0.000) \\
\end{array}$ & $\begin{array}{l}-0.355 \\
(-0.562) \\
\end{array}$ & $\begin{array}{c}0.554 \\
(1.345) \\
\end{array}$ \\
\hline & $b_{6}$ & $\begin{array}{l}0.288 \\
(5.659) *\end{array}$ & $\begin{array}{l}0.299 \\
(7.532) *\end{array}$ & $\begin{array}{c}0.222 \\
(5.068) \text { * }\end{array}$ & $\begin{array}{c}0.183 \\
(4.543) *\end{array}$ & $\begin{array}{c}0.321 \\
(6.074) *\end{array}$ \\
\hline
\end{tabular}

Panel B-2 (DEV included), Coefficients and (t-statistics)"

\begin{tabular}{|c|c|c|c|c|c|c|}
\hline & & $\begin{array}{l}\text { Whole } \\
1985-1993\end{array}$ & $\begin{array}{c}I \\
1985-1987\end{array}$ & $\begin{array}{c}I I \\
1987-1989\end{array}$ & $\begin{array}{c}\text { III } \\
1989-1991\end{array}$ & $\underset{1991-1993}{\text { IV }}$ \\
\hline LHS & Coef & $\#$ OBS $=192$ & $\#$ OBS $=48$ & \#OBS $=48$ & \#OBS $=48$ & \#OBS $=48$ \\
\hline \multirow[t]{3}{*}{ SE 1} & $a_{1}$ & $\begin{array}{l}-0.671 \\
(-6.743) *\end{array}$ & $\begin{array}{l}-1.387 \\
(-10.36) *\end{array}$ & $\begin{array}{c}-0.365 \\
(-1.164)\end{array}$ & $\begin{array}{l}-0.426 \\
(-3.358) *\end{array}$ & $\begin{array}{c}-0.213 \\
(-1.216)\end{array}$ \\
\hline & $b_{1}$ & $\begin{array}{l}-0.069 \\
(-3.460) \star\end{array}$ & $\begin{array}{l}-0.026 \\
(-1.077)\end{array}$ & $\begin{array}{l}-0.089 \\
(-3.020) *\end{array}$ & $\begin{array}{l}-0.035 \\
(-0.785)\end{array}$ & $\begin{array}{l}-0.020 \\
(-0.433)\end{array}$ \\
\hline & $c_{1}$ & $\begin{array}{l}-0.013 \\
(-2.169) \text { * }\end{array}$ & $\begin{array}{l}-0.017 \\
(-2.540) *\end{array}$ & $\begin{array}{l}-0.036 \\
(-1.818)\end{array}$ & $\begin{array}{l}-0.076 \\
(-2.147) *\end{array}$ & $\begin{array}{l}0.001 \\
(0.027)\end{array}$ \\
\hline \multirow[t]{3}{*}{ SE3 } & $a_{3}$ & $\begin{array}{l}-0.816 \\
(-2.878) \text { * }\end{array}$ & $\begin{array}{l}-1.547 \\
(-4.972) \text { * }\end{array}$ & $\begin{array}{l}-3.113 \\
(-7.667) *\end{array}$ & $\begin{array}{l}-0.470 \\
(-2.021)\end{array}$ & $\begin{array}{l}0.203 \\
(0.073)\end{array}$ \\
\hline & $b_{3}$ & $\begin{array}{c}0.054 \\
(1.447)\end{array}$ & $\begin{array}{c}0.116 \\
(3.754) \\
\end{array}$ & $\begin{array}{c}-0.026 \\
(-0.954)\end{array}$ & $\begin{array}{c}0.074 \\
(2.045) *\end{array}$ & $\begin{array}{l}-0.014 \\
(-0.350)\end{array}$ \\
\hline & $c_{3}$ & $\begin{array}{l}-0.040 \\
(-2.113) \star\end{array}$ & $\begin{array}{l}-0.015 \\
(-0.835) \star\end{array}$ & $\begin{array}{l}0.038 \\
(\quad 1.702) \\
\end{array}$ & $\begin{array}{c}-0.177 \\
(-4.576) *\end{array}$ & $\begin{array}{l}0.048 \\
(2.633) \star\end{array}$ \\
\hline \multirow[t]{3}{*}{ SE 6} & $a_{6}$ & $\begin{array}{c}-0.590 \\
(-1.482)\end{array}$ & $\begin{array}{c}-0.597 \\
(-1.689)\end{array}$ & $\begin{array}{c}-7.033 \\
(-9.279) *\end{array}$ & $\begin{array}{c}-0.315 \\
(-0.698)\end{array}$ & $\begin{array}{c}-0.112 \\
(-0.174)\end{array}$ \\
\hline & $b_{6}$ & $\begin{array}{c}0.290 \\
(6.131)^{\star}\end{array}$ & $\begin{array}{c}0.312 \\
(7.162) * \\
\end{array}$ & $\begin{array}{l}0.071 \\
(0.000) \\
\end{array}$ & $\begin{array}{l}0.193 \\
(2.326)^{*} \\
\end{array}$ & $\begin{array}{c}0.164 \\
(2.102)^{*}\end{array}$ \\
\hline & $c_{6}$ & $\begin{array}{l}-0.030 \\
(-1.104)\end{array}$ & $\left(\begin{array}{l}0.024 \\
1.074) *\end{array}\right.$ & $\begin{array}{c}0.223 \\
(10.080) \text { * }\end{array}$ & $\begin{array}{l}-0.026 \\
(-0.214)\end{array}$ & $\left(\begin{array}{l}0.162 \\
2.695) *\end{array}\right.$ \\
\hline
\end{tabular}


Table 3, Panel C (3-month change as a regressor) $\operatorname{sEk}(t)=a_{k}+b_{k} \operatorname{CHG} 3(t)+c_{k} \operatorname{DEV}(t)+e(t)$, where $\operatorname{CHG} 3(t)=100 *(\operatorname{SPOT}(t-6)-\operatorname{SPOT}(t)) / \operatorname{SPOT}(t)$ is the 2 -wk change; and $k=1,3,6$.

Panel $\mathrm{C}-1, \mathrm{c}_{\mathrm{k}}=0$ imposed. Coefficients and (t-statistics)"

\begin{tabular}{|c|c|c|c|c|c|c|}
\hline & & $\begin{array}{l}\text { Whole } \\
1985-1993\end{array}$ & $\begin{array}{c}I \\
1985-1987\end{array}$ & $\begin{array}{c}\text { II } \\
1987-1989\end{array}$ & $\begin{array}{c}\text { III } \\
1989-1991\end{array}$ & $\begin{array}{c}\text { IV } \\
1991-1993 \\
\end{array}$ \\
\hline LHS & Coef & $\# O b s=144$ & $\#$ Obs $=48$ & $\# O b s=48$ & $\#$ Obs $=48$ & $\# O b s=48$ \\
\hline \multirow[t]{2}{*}{ SE 1} & $a_{1}$ & $\begin{array}{l}-0.626 \\
(-7.608) \star\end{array}$ & $\begin{array}{l}-1.313 \\
(-10.15) *\end{array}$ & $\begin{array}{l}-0.979 \\
(-11.22) *\end{array}$ & $\begin{array}{l}-0.566 \\
(-4.778) *\end{array}$ & $\begin{array}{c}-0.148 \\
(-0.954) \\
\end{array}$ \\
\hline & $\mathrm{b}_{1}$ & $\begin{array}{l}-0.070 \\
(-6.834) \star \\
\end{array}$ & $\begin{array}{l}-0.029 \\
(-2.964) \star \\
\end{array}$ & $\begin{array}{l}-0.075 \\
(-6.325) \star \\
\end{array}$ & $\begin{array}{l}-0.088 \\
(-6.081) \star \\
\end{array}$ & $\begin{array}{l}-0.027 \\
(-1.091) \\
\end{array}$ \\
\hline \multirow[t]{2}{*}{ SE3 } & $a_{3}$ & $\begin{array}{l}-1.015 \\
(-3.104) \star \\
\end{array}$ & $\begin{array}{l}-2.037 \\
(-11.46) * \\
\end{array}$ & $\begin{array}{l}-2.381 \\
(-13.95) * \\
\end{array}$ & $\begin{array}{l}-0.758 \\
(-2.069) * \\
\end{array}$ & $\begin{array}{l}0.380 \\
(1.379) \\
\end{array}$ \\
\hline & $\mathrm{b}_{3}$ & $\begin{array}{l}0.000 \\
(0.005) \\
\end{array}$ & $\begin{array}{l}0.079 \\
(2.605) * \\
\end{array}$ & $\begin{array}{l}-0.003 \\
(-0.028) \\
\end{array}$ & $\begin{array}{r}-0.054 \\
(-1.258) \\
\end{array}$ & $\begin{array}{l}0.020 \\
(0.383) \\
\end{array}$ \\
\hline \multirow[t]{2}{*}{ SE6 } & $a_{6}$ & $\begin{array}{c}-1.029 \\
(-1.936) \\
\end{array}$ & $\begin{array}{l}-1.540 \\
(-4.157) * \\
\end{array}$ & $\begin{array}{l}-2.978 \\
(-20.73) *\end{array}$ & $\begin{array}{l}-0.324 \\
(-0.628) \\
\end{array}$ & $\begin{array}{c}0.082 \\
(0.254) \\
\end{array}$ \\
\hline & $\mathrm{b}_{6}$ & $\begin{array}{l}0.197 \\
(4.330) *\end{array}$ & $\begin{array}{l}0.243 \\
(3.685) *\end{array}$ & $\begin{array}{c}0.205 \\
(10.02) \text { * }\end{array}$ & $\begin{array}{c}0.125 \\
(1.920)\end{array}$ & $\begin{array}{c}0.271 \\
(8.593) \text { * }\end{array}$ \\
\hline
\end{tabular}

Panel C-2 (DEV included), Coefficients and (t-statistics)"

\begin{tabular}{|c|c|c|c|c|c|c|}
\hline & & $\begin{array}{l}\text { Whole } \\
1985-1993\end{array}$ & $\begin{array}{c}I \\
1985-1987\end{array}$ & $\begin{array}{c}\text { II } \\
1987-1989\end{array}$ & $\begin{array}{c}\text { III } \\
1989-1991\end{array}$ & $\begin{array}{c}\text { IV } \\
1991-1993\end{array}$ \\
\hline LHS & Coef & $\#$ OBS $=192$ & $\#$ OBS $=48$ & $\# O B S=48$ & $\# O B S=48$ & $\# O B S=48$ \\
\hline \multirow[t]{3}{*}{ SE1 } & $a_{1}$ & $\begin{array}{c}-0.537 \\
(-6.743) \star \\
\end{array}$ & $\begin{array}{c}-1.128 \\
(-9.484)\end{array}$ & $\begin{array}{l}-0.832 \\
(-2.094) * \\
\end{array}$ & $\begin{array}{c}-0.501 \\
(-5.744) * \\
\end{array}$ & $\begin{array}{c}-0.209 \\
(-1.311) \\
\end{array}$ \\
\hline & $\mathrm{b}_{1}$ & $\begin{array}{l}-0.069 \\
(-6.982) *\end{array}$ & $\begin{array}{c}-0.045 \\
(-4.031)\end{array}$ & $\begin{array}{l}-0.071 \\
(-4.425) *\end{array}$ & $\begin{array}{l}-0.075 \\
(-3.817) \star\end{array}$ & $\begin{array}{c}-0.055 \\
(-1.487)\end{array}$ \\
\hline & $c_{1}$ & $\begin{array}{l}-0.013 \\
(-3.025) *\end{array}$ & $\begin{array}{l}-0.017 \\
(-3.496) *\end{array}$ & $\begin{array}{c}-0.008 \\
(-0.383)\end{array}$ & $\begin{array}{c}-0.040 \\
(-1.695)\end{array}$ & $\begin{array}{l}0.029 \\
(0.874) \\
\end{array}$ \\
\hline \multirow[t]{3}{*}{ SE3 } & $a_{3}$ & $\begin{array}{l}-0.768 \\
(-2.642) *\end{array}$ & $\begin{array}{l}-1.806 \\
(-7.103) *\end{array}$ & $\begin{array}{l}-3.396 \\
(-7.392) \star\end{array}$ & $\begin{array}{l}-0.506 \\
(-2.645) * \\
\end{array}$ & $\begin{array}{l}0.208 \\
(\quad 0.919) \\
\end{array}$ \\
\hline & $b_{3}$ & $\begin{array}{c}0.002 \\
(0.048)\end{array}$ & $\begin{array}{c}0.062 \\
(1.459) \\
\end{array}$ & $\begin{array}{c}-0.033 \\
(-1.790)\end{array}$ & $\begin{array}{c}0.005 \\
(0.220)\end{array}$ & $\begin{array}{l}-0.060 \\
(-1.289)\end{array}$ \\
\hline & $c_{3}$ & $\begin{array}{l}-0.040 \\
(-2.212) *\end{array}$ & $\begin{array}{l}-0.012 \\
(-0.656) * \\
\end{array}$ & $\begin{array}{l}0.054 \\
(2.095) * \\
\end{array}$ & $\begin{array}{l}-0.155 \\
(-3.764) *\end{array}$ & $\begin{array}{l}0.080 \\
(5.883) * \\
\end{array}$ \\
\hline \multirow[t]{3}{*}{ SE6 } & $a_{6}$ & $\begin{array}{c}-0.878 \\
(-1.822) \\
\end{array}$ & $\begin{array}{c}-1.727 \\
(-3.913) \\
\end{array}$ & $\begin{array}{l}-5.945 \\
(-10.86) *\end{array}$ & $\begin{array}{l}-0.220 \\
(-0.697) \\
\end{array}$ & $\begin{array}{c}-0.108 \\
(-0.188) \\
\end{array}$ \\
\hline & $b_{6}$ & $\begin{array}{c}0.198 \\
(4.320)^{*} \\
\end{array}$ & $\begin{array}{c}0.264 \\
(4.319) * \\
\end{array}$ & $\begin{array}{l}0.117 \\
(3.837) * \\
\end{array}$ & $\begin{array}{l}0.145 \\
(1.636) * \\
\end{array}$ & $\begin{array}{r}0.182 \\
(1.587) \\
\end{array}$ \\
\hline & $c_{6}$ & $\begin{array}{c}-0.032 \\
(-0.941)\end{array}$ & $\begin{array}{l}0.035 \\
(2.222) *\end{array}$ & $\begin{array}{l}0.159 \\
(6.659) *\end{array}$ & $\begin{array}{l}-0.064 \\
(-0.548)\end{array}$ & $\begin{array}{l}0.089 \\
(0.932)\end{array}$ \\
\hline
\end{tabular}

Notes: (a) All regressions are estimated with GMM (Generalized Method of Moments). (*) An asterisk refers to the estimated coefficient that is significant at the level of $5 \%$. 
Table 4, Expectation Formation, Specification III:

past forecast errors and forward premium added on the RHS

$$
\operatorname{SEk}(t)=a_{k}+b_{k} \operatorname{CHG} 1(t)+c_{k} \text { FEk }(t)+d_{k} \text { FOk }(t)+e(t)
$$

where $k=1,3,6$

Coefficients and (t-statistics)"

\begin{tabular}{|c|c|c|c|c|c|c|}
\hline & & $\begin{array}{l}\text { Whole } \\
1985-1993\end{array}$ & $\begin{array}{c}I \\
1985-1987 \\
\end{array}$ & $\begin{array}{c}\text { II } \\
\text { 1987-1989 }\end{array}$ & $\begin{array}{c}\text { III } \\
1989-1991 \\
\end{array}$ & $\begin{array}{c}\text { IV } \\
1991-1993 \\
\end{array}$ \\
\hline LHS & Coef & $\# \mathrm{OBS}^{\mathrm{b}}$ & $\#$ OBS $^{\mathrm{c}}$ & \#OBS $=48$ & $\# O B S=46^{d}$ & $\# O B S=44^{d}$ \\
\hline \multirow[t]{4}{*}{ SE 1} & $a_{1}$ & $\begin{array}{c}-0.189 \\
(-2.479) \star\end{array}$ & $\begin{array}{c}-0.925 \\
(-3.151) \star\end{array}$ & $\begin{array}{l}0.052 \\
(0.141) \\
\end{array}$ & $\begin{array}{l}-0.233 \\
(-1.746) \star\end{array}$ & $\begin{array}{l}-0.178 \\
(-1.480) \\
\end{array}$ \\
\hline & $b_{1}$ & $\begin{array}{c}-0.667 \\
(-9.449) * \\
\end{array}$ & $\begin{array}{l}-0.347 \\
(-2.105) \star \\
\end{array}$ & $\begin{array}{l}-0.529 \\
(-7.526) \star \\
\end{array}$ & $\begin{array}{l}-0.760 \\
(-4.543)\end{array}$ & $\begin{array}{l}-0.420 \\
(-2.295) \star\end{array}$ \\
\hline & $c_{1}$ & $\begin{array}{l}0.590 \\
(8.316) *\end{array}$ & $\begin{array}{c}0.331 \\
(2.020) \text { * }\end{array}$ & $\left(\begin{array}{l}0.396 \\
5.630) \text { * }\end{array}\right.$ & $\begin{array}{l}0.067 \\
(4.087) *\end{array}$ & $\begin{array}{l}0.369 \\
(2.108) *\end{array}$ \\
\hline & $d_{1}$ & $\begin{array}{l}0.665 \\
(2.449)^{*} \\
\end{array}$ & $\begin{array}{l}0.081 \\
(\quad 0.157) \\
\end{array}$ & $\begin{array}{r}2.063 \\
(1.780) \\
\end{array}$ & $\begin{array}{l}-0.587 \\
(-0.924) \\
\end{array}$ & $\begin{array}{l}1.026 \\
(3.906) * \\
\end{array}$ \\
\hline \multirow[t]{4}{*}{ SE3 } & $a_{3}$ & $\begin{array}{c}-0.411 \\
(-1.463)\end{array}$ & $\begin{array}{c}-1.294 \\
(-6.946) *\end{array}$ & $\begin{array}{c}-1.835 \\
(-2.369) *\end{array}$ & $\begin{array}{c}-0.689 \\
(-1.851)\end{array}$ & $\begin{array}{l}0.512 \\
(1.911) \\
\end{array}$ \\
\hline & $\mathrm{b}_{3}$ & $\begin{array}{c}0.068 \\
(2.752) * \\
\end{array}$ & $\begin{array}{c}0.127 \\
(4.122) * \\
\end{array}$ & $\begin{array}{c}-0.004 \\
(-0.133)\end{array}$ & $\begin{array}{c}0.085 \\
(2.014) *\end{array}$ & $\begin{array}{c}0.014 \\
(1.056)\end{array}$ \\
\hline & $c_{3}$ & $\begin{array}{l}-0.032 \\
(-1.002)\end{array}$ & $\begin{array}{c}0.013 \\
(0.323)\end{array}$ & $\begin{array}{l}-0.010 \\
(-0.680)\end{array}$ & $\begin{array}{l}-0.089 \\
(-2.127) *\end{array}$ & $\begin{array}{l}0.017 \\
(0.421)\end{array}$ \\
\hline & $d_{3}$ & $\begin{array}{l}1.842 \\
(5.919) * \\
\end{array}$ & $\begin{array}{c}1.406 \\
(0.000)\end{array}$ & $\begin{array}{c}0.581 \\
(0.793)\end{array}$ & $\begin{array}{l}0.802 \\
(1.764)\end{array}$ & $\begin{array}{l}-0.741 \\
(-2.139) *\end{array}$ \\
\hline \multirow[t]{4}{*}{ SE 6} & $a_{6}$ & $\begin{array}{l}-0.022 \\
(-0.032) \\
\end{array}$ & $\begin{array}{l}-1.111 \\
(-0.842) \\
\end{array}$ & $\begin{array}{c}-6.138 \\
(-5.602) *\end{array}$ & $\begin{array}{c}-0.281 \\
(-0.716) \\
\end{array}$ & $\begin{array}{c}-0.261 \\
(-0.392) \\
\end{array}$ \\
\hline & $b_{6}$ & $\begin{array}{c}0.124 \\
(7.878) *\end{array}$ & $\begin{array}{c}0.158 \\
(7.421) *\end{array}$ & $\begin{array}{l}0.116 \\
(3.484) * \\
\end{array}$ & $\begin{array}{l}0.065 \\
(1.841) \\
\end{array}$ & $\begin{array}{c}0.204 \\
(3.831)^{*}\end{array}$ \\
\hline & $c_{6}$ & $\begin{array}{c}0.071 \\
(2.953)^{*}\end{array}$ & $\begin{array}{c}0.123 \\
(3.063) *\end{array}$ & $\begin{array}{c}0.234 \\
(15.08)^{*} \\
\end{array}$ & $\begin{array}{c}0.089 \\
(2.060) * \\
\end{array}$ & $\begin{array}{c}0.167 \\
(3.137)^{\star}\end{array}$ \\
\hline & $d_{6}$ & $\begin{array}{l}1.326 \\
(3.594) *\end{array}$ & $\begin{array}{c}1.077 \\
(0.835)\end{array}$ & $\begin{array}{c}-1.591 \\
(-3.385) *\end{array}$ & $----^{e}$ & $---0^{\circ}$ \\
\hline
\end{tabular}

Notes: (a) Generalized Method of Moments (GMM) is used. (b). The number of observations for the SE1 equation is 184; and the SE3 equation 180, because the forecast errors (FE) variables are not available at the beginning of the sample. The number of observations for the equation of SE6 is 120 , because, in addition to the beginning of the sample, the data for the 6-month forward rate is not available after January 1991. (c) The number of observations for the SE1 equation is 46 , the SE3 equation 42 , the SE6 equation 36 , because of the reason mentioned in (a). (d) The number of observations is less than 48 (in Table 3) because the week of missing data reduces that week and also $2 \mathrm{k}$ weeks later for FE variables. (e) The variable FO6 is not available for these period, see (b) above. 
Table 5: Expectation Formation: specification IV $\operatorname{SEk}(t)=a_{k}+b_{k} \operatorname{CHG} 1(t)+c_{k}$ FEk $(t)+d_{k} F O k(t)+g_{k} \operatorname{DEV}(t)+e(t)$

where $k=1,3,6$

Coefficients and (t-statistics)"

\begin{tabular}{|c|c|c|c|c|c|c|}
\hline & & $\begin{array}{l}\text { Whole } \\
1985-1993\end{array}$ & $\begin{array}{c}I \\
1985-1987\end{array}$ & $\begin{array}{c}\text { II } \\
1987-1989\end{array}$ & $\begin{array}{c}\text { III } \\
1989-1991\end{array}$ & $\begin{array}{c}\text { IV } \\
1991-1993\end{array}$ \\
\hline LHS & Coef & $\# \mathrm{OBS}^{\mathrm{b}}$ & $\# \mathrm{OBS}^{\mathrm{c}}$ & $\# O B S=48$ & $\# O B S=46^{d}$ & $\# O B S=44^{d}$ \\
\hline \multirow[t]{5}{*}{ SEI } & $a_{1}$ & $\begin{array}{c}-0.184 \\
(-2.370) *\end{array}$ & $\begin{array}{l}-1.087 \\
(-3.684) *\end{array}$ & $\begin{array}{l}0.409 \\
(0.700) \\
\end{array}$ & $\begin{array}{c}-0.297 \\
(-2.241)^{*}\end{array}$ & $\begin{array}{c}-0.218 \\
(-1.184)\end{array}$ \\
\hline & $b_{1}$ & $\begin{array}{l}-0.664 \\
(-9.441) *\end{array}$ & $\begin{array}{l}-0.261 \\
(-1.612) *\end{array}$ & $\begin{array}{c}-0.445 \\
(-6.234) *\end{array}$ & $\begin{array}{c}-0.587 \\
(-3.680) *\end{array}$ & $\begin{array}{l}-0.419 \\
(-2.327) *\end{array}$ \\
\hline & $c_{1}$ & $\begin{array}{l}0.588 \\
(8.278) * \\
\end{array}$ & $\begin{array}{c}0.243 \\
(1.533) *\end{array}$ & $\begin{array}{l}0.327 \\
(4.629)^{*} \\
\end{array}$ & $\left(\begin{array}{l}0.521 \\
3.392) *\end{array}\right.$ & $\begin{array}{l}0.363 \\
(2.093) * \\
\end{array}$ \\
\hline & $d_{1}$ & $\begin{array}{c}0.625 \\
(2.119) * \\
\end{array}$ & $\begin{array}{c}-0.139 \\
(-0.211) \\
\end{array}$ & $\begin{array}{c}2.215 \\
(1.909) \\
\end{array}$ & $\begin{array}{c}-1.052 \\
(-1.541) \\
\end{array}$ & $\begin{array}{c}1.106 \\
(3.554) \\
\end{array}$ \\
\hline & $g_{1}$ & $\begin{array}{c}-0.002 \\
(-0.423)\end{array}$ & $\begin{array}{c}-0.009 \\
(-1.381) \\
\end{array}$ & $\begin{array}{c}-0.020 \\
(-1.226) \\
\end{array}$ & $\begin{array}{c}-0.035 \\
(-1.603) \\
\end{array}$ & $\begin{array}{l}0.007 \\
(0.281) \\
\end{array}$ \\
\hline \multirow[t]{5}{*}{ SE3 } & $a_{3}$ & $\begin{array}{c}-0.388 \\
(-1.348) \\
\end{array}$ & $\begin{array}{c}-1.327 \\
(-10.32) *\end{array}$ & $\begin{array}{c}-2.934 \\
(-7.331) *\end{array}$ & $\begin{array}{c}-0.491 \\
(-2.790) *\end{array}$ & $\begin{array}{l}0.211 \\
(0.774) \\
\end{array}$ \\
\hline & $\mathrm{b}_{3}$ & $\begin{array}{c}0.070 \\
(2.670) * \\
\end{array}$ & $\begin{array}{c}0.120 \\
(2.591) \star \\
\end{array}$ & $\begin{array}{c}-0.002 \\
(-0.083) \\
\end{array}$ & $\begin{array}{c}0.136 \\
(4.465)^{*}\end{array}$ & $\begin{array}{c}0.017 \\
(0.413) \\
\end{array}$ \\
\hline & $c_{3}$ & $\begin{array}{c}-0.032 \\
(-0.994) \\
\end{array}$ & $\begin{array}{c}0.027 \\
(0.436) \\
\end{array}$ & $\begin{array}{c}-0.041 \\
(-1.852) \\
\end{array}$ & $\begin{array}{l}-0.070 \\
(-2.575) *\end{array}$ & $\begin{array}{c}-0.052 \\
(-1.491) \\
\end{array}$ \\
\hline & $d_{3}$ & $\begin{array}{c}1.768 \\
(4.807) *\end{array}$ & $\begin{array}{c}1.519 \\
(0.000) \\
\end{array}$ & $\begin{array}{c}0.613 \\
(1.173) \\
\end{array}$ & $\begin{array}{c}0.514 \\
(2.826) *\end{array}$ & $\begin{array}{c}-0.109 \\
(-0.293) \\
\end{array}$ \\
\hline & $g_{3}$ & $\begin{array}{c}-0.007 \\
(-0.384)\end{array}$ & $\begin{array}{c}0.012 \\
(0.383) \\
\end{array}$ & $\begin{array}{c}0.056 \\
(2.751) *\end{array}$ & $\begin{array}{c}-0.167 \\
(-5.098) *\end{array}$ & $\begin{array}{l}0.077 \\
(4.199) * \\
\end{array}$ \\
\hline \multirow[t]{5}{*}{$\mathrm{SE} 6$} & $a_{6}$ & $\begin{array}{c}-0.041 \\
(-0.061) \\
\end{array}$ & $\begin{array}{c}-1.254 \\
(-0.846) \\
\end{array}$ & $\begin{array}{c}-7.878 \\
(-7.829) *\end{array}$ & $\begin{array}{c}-0.004 \\
(-0.016) \\
\end{array}$ & $\begin{array}{c}-0.263 \\
(-0.407) \\
\end{array}$ \\
\hline & $b_{6}$ & $\begin{array}{c}0.125 \\
(10.195) *\end{array}$ & $\begin{array}{c}0.118 \\
(9.393) *\end{array}$ & $\begin{array}{l}0.050 \\
(2.209) * \\
\end{array}$ & $\begin{array}{l}0.086 \\
(3.684)^{*} \\
\end{array}$ & $\begin{array}{c}0.207 \\
(2.183) * \\
\end{array}$ \\
\hline & $c_{6}$ & $\begin{array}{c}0.071 \\
(3.305) * \\
\end{array}$ & $\begin{array}{c}0.166 \\
(3.286) * \\
\end{array}$ & $\begin{array}{l}0.150 \\
(3.886) * \\
\end{array}$ & $\begin{array}{c}0.120 \\
(4.425) * \\
\end{array}$ & $\begin{array}{c}0.175 \\
(2.092) * \\
\end{array}$ \\
\hline & $d_{6}$ & $\begin{array}{c}1.277 \\
(3.613) *\end{array}$ & $\begin{array}{c}2.067 \\
(1.991) *\end{array}$ & $\begin{array}{l}-1.023 \\
(-2.189) *\end{array}$ & $--^{e}$ & $--\infty$ \\
\hline & $g_{6}$ & $\begin{array}{l}-0.005 \\
(-0.282)\end{array}$ & $\begin{array}{c}0.098 \\
(1.734)\end{array}$ & $\begin{array}{l}0.153 \\
(6.858) *\end{array}$ & $\begin{array}{l}-0.152 \\
(-2.558) *\end{array}$ & $\begin{array}{c}-0.008 \\
(-0.070)\end{array}$ \\
\hline
\end{tabular}

Notes: see Table 4 . 
YEN/DOLLAR RATE, $73-94$

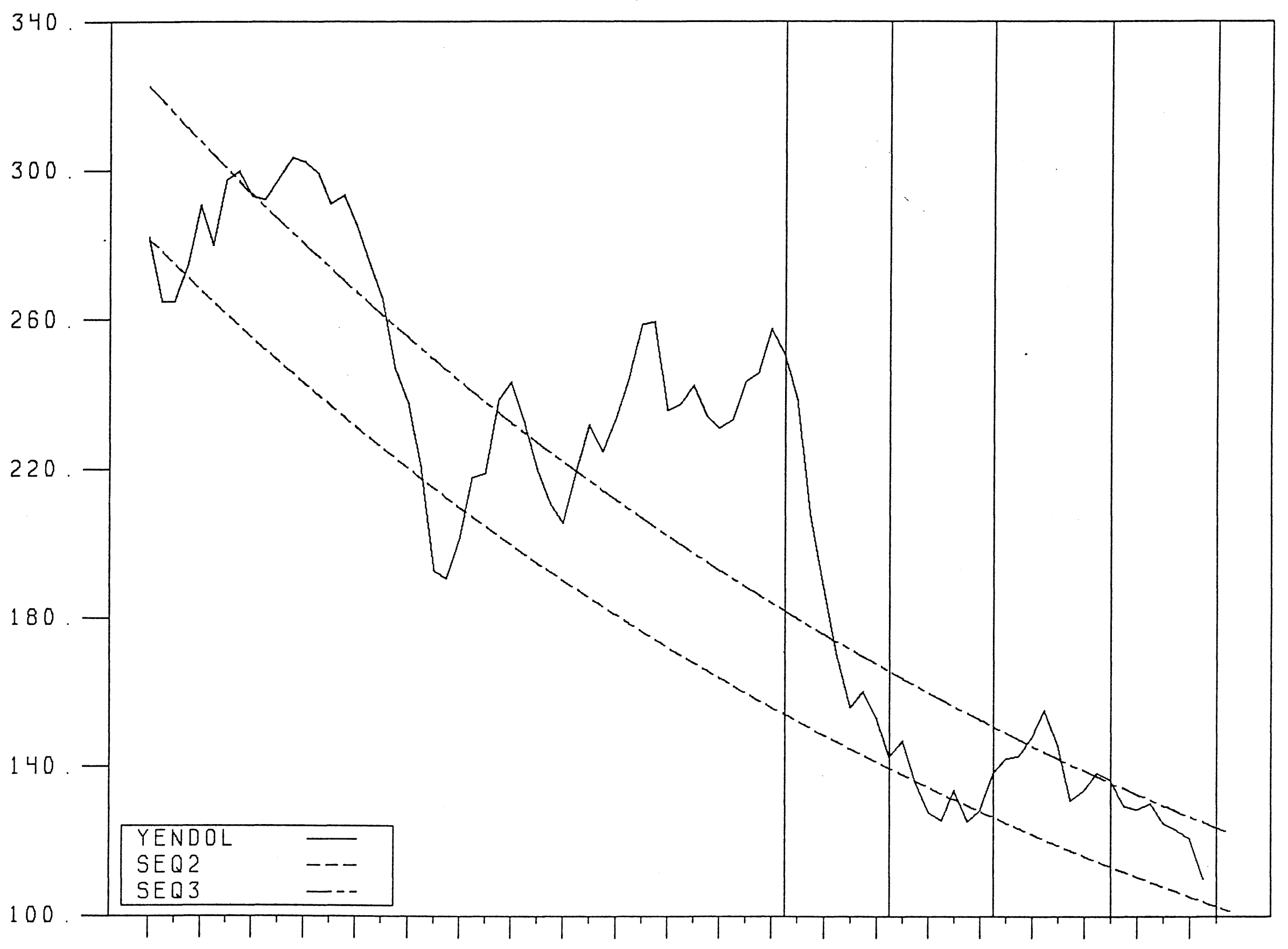

$\begin{array}{lllllllllllllllllllll}73 & 74 & 75 & 76 & 77 & 78 & 79 & 80 & 81 & 82 & 83 & 84 & 85 & 86 & 87 & 88 & 89 & 90 & 91 & 92 & 93\end{array}$ 


\begin{tabular}{|c|c|c|c|}
\hline Quarter & YENDOL & SEQ2 & SEQ3 \\
\hline $73: 01$ & 282.11 & 281.75 & 322.53 \\
\hline $73: 02$ & 264.98 & 278.30 & 318.78 \\
\hline $73: 03$ & 265.00 & 274.90 & 315.08 \\
\hline $73: 04$ & 274.71 & 271.53 & 311.42 \\
\hline $74: 01$ & 290.82 & 268.21 & 307.80 \\
\hline $74: 02$ & 279.92 & 264.93 & 304.22 \\
\hline $74: 03$ & 297.58 & 261.69 & 300.68 \\
\hline $74: 04$ & 300.01 & 258.48 & 297.19 \\
\hline $75: 01$ & 293.28 & 255.32 & 293.74 \\
\hline $75: 02$ & 292.39 & 252.20 & 290.32 \\
\hline $75: 03$ & 297.95 & 249.11 & 286.95 \\
\hline $75: 04$ & 303.54 & 246.06 & 283.61 \\
\hline $76: 01$ & 302.39 & 243.05 & 280.32 \\
\hline $76: 02$ & 299.20 & 240.08 & 277.06 \\
\hline $76: 03$ & 291.06 & 237.14 & 273.84 \\
\hline $76: 04$ & 293.57 & 234.24 & 270.66 \\
\hline $77: 01$ & 285.57 & 231.37 & 267.51 \\
\hline $77: 02$ & 275.24 & 228.54 & 264.40 \\
\hline $77: 03$ & 266.17 & 225.74 & 261.33 \\
\hline $77: 04$ & 247.06 & 222.98 & 258.29 \\
\hline $78: 01$ & 237.64 & 220.25 & 255.29 \\
\hline $78: 02$ & 220.81 & 217.56 & 252.32 \\
\hline $78: 03$ & 192.84 & 214.89 & 249.39 \\
\hline $78: 04$ & 190.48 & 212.26 & 246.49 \\
\hline $79: 01$ & 201.46 & 209.67 & 243.63 \\
\hline $79: 02$ & 217.62 & 207.10 & 240.80 \\
\hline $79: 03$ & 218.86 & 204.57 & 238.00 \\
\hline $79: 04$ & 238.62 & 202.06 & 235.23 \\
\hline $80: 01$ & 243.53 & 199.59 & 232.50 \\
\hline $80: 02$ & 232.69 & 197.15 & 229.80 \\
\hline $80: 03$ & 220.08 & 194.73 & 227.12 \\
\hline $80: 04$ & 210.67 & 192.35 & 224.49 \\
\hline $81: 01$ & 205.57 & 190.00 & 221.88 \\
\hline $81: 02$ & 220.00 & 187.67 & 219.30 \\
\hline $81: 03$ & 231.89 & 185.38 & 216.75 \\
\hline $81: 04$ & 224.65 & 183.11 & 214.23 \\
\hline $82: 01$ & 233.49 & 180.87 & 211.74 \\
\hline $82: 02$ & 244.27 & 178.65 & 209.28 \\
\hline $82: 03$ & 258.88 & 176.47 & 206.85 \\
\hline $82: 0$ & 259.68 & 174.31 & 204.44 \\
\hline $83: 01$ & 235.74 & 172.17 & 202.07 \\
\hline $83: 02$ & 237.53 & 170.07 & 199.72 \\
\hline $83: 03$ & 242.53 & 167.99 & 197.40 \\
\hline $83: 04$ & 234.24 & 165.93 & 195.10 \\
\hline $84: 01$ & 230.91 & 163.90 & 192.84 \\
\hline $84: 02$ & 233.36 & 161.89 & 190.59 \\
\hline $84: 03$ & 243.36 & 159.91 & 188.38 \\
\hline $84: 04$ & 246.03 & 157.96 & 186.19 \\
\hline $85: 01$ & 257.70 & 156.02 & 184.03 \\
\hline $85: 02$ & 250.74 & 154.11 & 181.89 \\
\hline $85: 03$ & 238.76 & 152.23 & 179.77 \\
\hline
\end{tabular}




$\begin{array}{llll}85: 04 & 207.20 & 150.37 & 177.68 \\ 86: 01 & 187.73 & 148.53 & 175.62 \\ 86: 02 & 170.11 & 146.71 & 173.58 \\ 86: 03 & 155.88 & 144.91 & 171.56 \\ 86: 04 & 160.14 & 143.14 & 169.57 \\ 87: 01 & 153.09 & 141.39 & 167.60 \\ 87: 02 & 142.76 & 139.66 & 165.65 \\ 87: 03 & 147.09 & 137.95 & 163.72 \\ 87: 04 & 135.62 & 136.26 & 161.82 \\ 88: 01 & 127.98 & 134.59 & 159.94 \\ 88: 02 & 125.61 & 132.95 & 158.08 \\ 88: 03 & 133.71 & 131.32 & 156.24 \\ 88: 04 & 125.28 & 129.71 & 154.43 \\ 89: 01 & 128.55 & 128.12 & 152.63 \\ 89: 02 & 138.26 & 126.56 & 150.86 \\ 89: 03 & 142.22 & 125.01 & 149.11 \\ 89: 04 & 143.01 & 123.48 & 147.37 \\ 90: 01 & 148.07 & 121.97 & 145.66 \\ 90: 02 & 155.20 & 120.47 & 143.97 \\ 90: 03 & 145.56 & 119.00 & 142.29 \\ 90: 04 & 130.80 & 117.54 & 140.64 \\ 91: 01 & 133.92 & 116.10 & 139.01 \\ 91: 02 & 138.30 & 114.68 & 137.39 \\ 91: 03 & 136.47 & 113.28 & 135.79 \\ 91: 04 & 129.50 & 111.89 & 134.22 \\ 92: 01 & 128.56 & 110.52 & 132.66 \\ 92: 02 & 130.25 & 109.17 & 131.11 \\ 92: 03 & 124.95 & 107.84 & 129.59 \\ 92: 04 & 122.94 & 106.52 & 128.08 \\ 93: 01 & 120.75 & 105.21 & 126.59 \\ 93: 02 & 110.00 & 103.93 & 125.12\end{array}$

NOTES: SPOT = Quarterly average of daily closing rates, Tokyo. SEQ2 = Benchmark, $1973: 2$ = average of $1972: 4-1973: 3$
$1979: 2=$ average of 1978:4-1979:3
Interpolate and Extrapolate other quarters.

SEQ3 = Regress $\log (\mathrm{SPOT})$ on Constant and time trend, Take the fitted value. 